\title{
THE CALIFORNIA COASTAL COMMISSION'S APPROACH TO LOWER COST OVERNIGHT VISITOR-SERVING ACCOMMODATIONS MITIGATION: \\ A POLICY AND LEGAL ANALYSIS
}

\author{
A Project \\ presented to \\ the Faculty of California Polytechnic State University, \\ San Luis Obispo
}

In Partial Fulfillment

of the Requirements for the Degree

Master of City and Regional Planning

by

David Francis Pierucci

June 2015 
(C) 2015

David Francis Pierucci

ALL RIGHTS RESERVED 


\section{COMMITTEE MEMBERSHIP}

TITLE:

The California Coastal Commission's Approach to Lower Cost Overnight Visitor-Serving Accommodations Mitigation: A Policy and Legal Analysis

AUTHOR: $\quad$ David Francis Pierucci

DATE SUBMITTED: June 2015

COMMITTEE CHAIR: $\quad$ Michael R. Boswell, Ph.D.

Professor of City and Regional Planning

COMMITTEE MEMBER: Chris William Clark, J.D.

Lecturer of City and Regional Planning

COMMITTEE MEMBER: Menka Sethi, M.B.A.

Director of Lisa Wise Consulting, Inc. 


\begin{abstract}
The California Coastal Commission's Approach to Lower Cost Overnight VisitorServing Accommodations Mitigation: A Policy and Legal Analysis

David Francis Pierucci
\end{abstract}

\begin{abstract}
Section 30213 of California Coastal Act requires the California Coastal Commission ("CCC") to protect, encourage, and, where feasible, provide for lower cost overnight visitor accommodations ("LCOVA") along the State's coast. As mitigation measure consistent with this charge, the CCC imposes a $\$ 30,000$ fee for 25 percent for rooms of new hotel developments determined to be higher cost (the " $\$ 30,000 / 25 \%$ fee"), in-lieu of LCOVA facility provision. Generally, the CCC applies this fee in two circumstances: (1) As an ad hoc fee for developers upon CCC review of coastal development permit ("CDP") applications, and (2) as a legislatively imposed fee to be adopted by coastal jurisdictions upon CCC review of a local coastal program ("LCP") or related policy. This paper explores the policy and legal implications of the $\$ 30,000 / 25 \%$ fee. The findings of this paper show that the $\$ 30,000 / 25 \%$ fee likely fails the applicable Federal California legal tests governing monetary exactions.
\end{abstract}

Keywords: California Coastal Commission, lower cost visitor-serving accommodations, monetary exactions. 


\section{ACKNOWLEDGMENTS}

I would like to thank my committee members, Michael Boswell, Chris Clark, and Menka Sethi for their time and support. I would also like to thank Lisa Wise and Henry Pontarelli of Lisa Wise Consulting, Inc. who offered me the extraordinary opportunity to join their firm and engage in projects such as this.

Thank you to my father, Richard Pierucci, mother, Rita Pierucci, sister, Katherine Pierucci, brother, John Pierucci, father-in-law, Michael Hodgkins, and mother-in-law, Connie Hodgkins for their encouragement through yet another graduate degree.

Finally, thank you to my wonderful wife and best friend, Jessica Pierucci. I would not have become a city planner without her love, kindness, and unyielding support of my dreams. 


\section{TABLE OF CONTENTS}

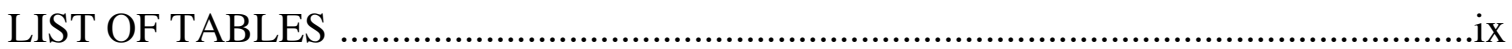

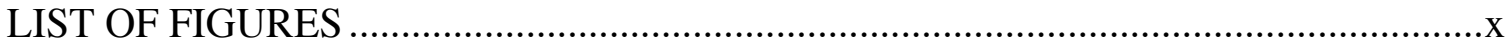

CHAPTER 1. BACKGROUND AND PURPOSE .........................................................

CHAPTER 2. THE CCC AND LCOVA MITIGATION POLICY ....................................6

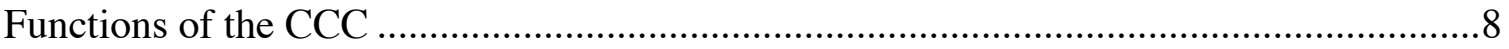

Coastal Development Permits .................................................................

Local Coastal Programs ................................................................................

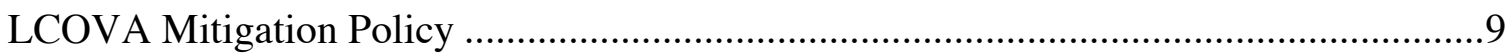

Supporting Statutes .....................................................................................10

The LCOVA Mitigation Toolbox ...................................................................11

CHAPTER 3. LCOVA IN-LIEU FEE FORMULATION …........................................13

Defining Local Low, Moderate, and High Cost Rates .....................................................13

Determine Statewide Hotel Average Daily Rate ...................................................14

Geographic Zone of Local Hotels Surveyed .....................................................15

Identify the Local Low, Moderate, and High Cost Ranges ..................................16

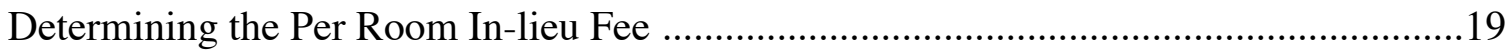

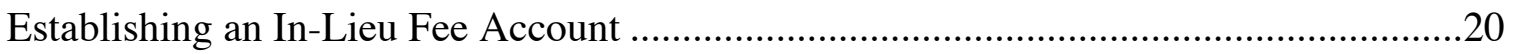

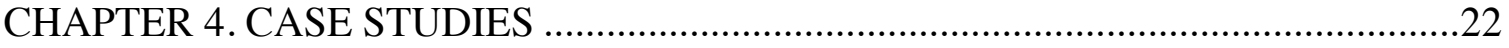

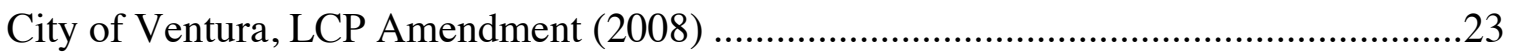

Defining Local Low, Moderate, and High Cost Rates .......................................24

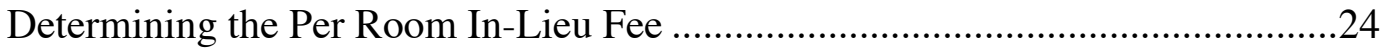


Establishing an In-Lieu Fee Account .......................................................24

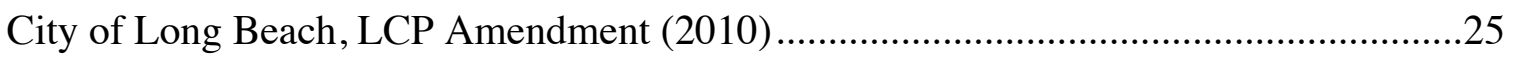

Defining Local Low, Moderate, and High Cost Rates ......................................25

Determining the Per Room In-Lieu Fee .................................................26

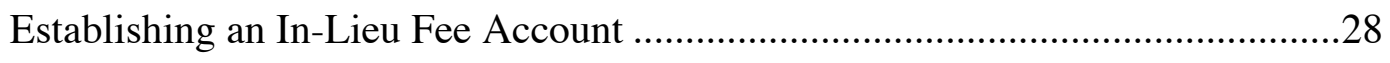

City of Solana Beach, LCP Land Use Plan (2012) .....................................................28

Defining Local Low, Moderate, and High Cost Rates ......................................28

Determining the Per Room In-Lieu Fee ...................................................... 30

Establishing an In-Lieu Fee Account ....................................................... 30

City of San Diego, 2200 Lee Court Project (2014) .....................................................30

Defining Local Low, Moderate, and High Cost Rates ...................................... 31

Determining the Per Room In-Lieu Fee ........................................................33

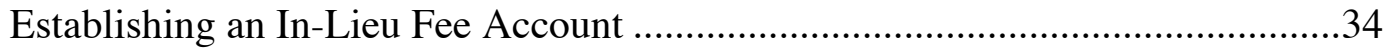

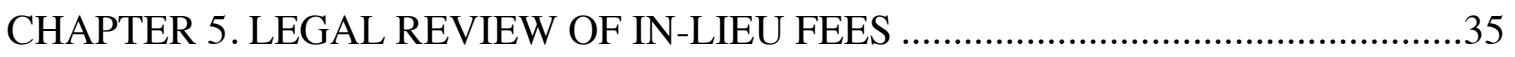

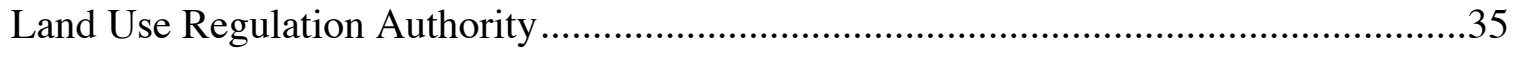

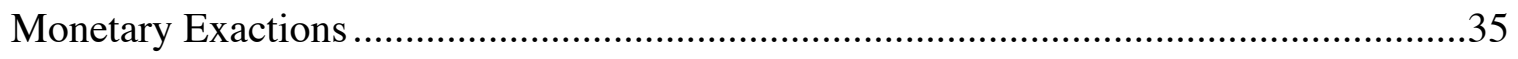

Ad Hoc Fees vs. Legislatively Imposed Fees .......................................................36

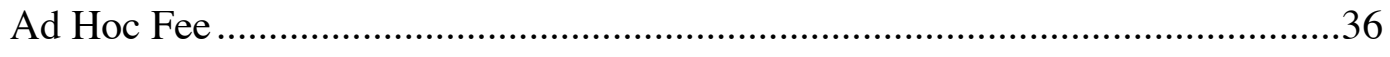

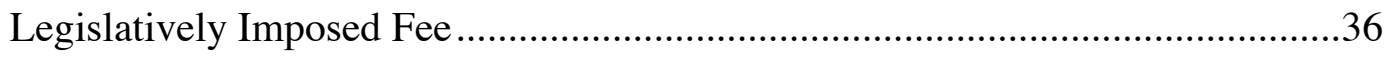

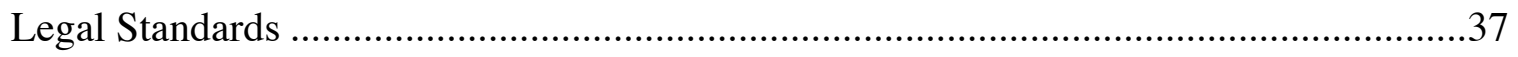

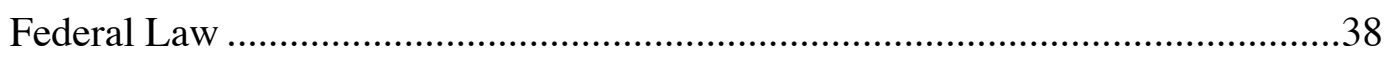

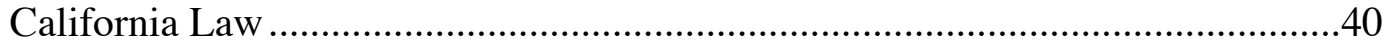

CHAPTER 6. LEGALITY OF THE \$30,000/25\% FEE ..............................................42 
As an Ad Hoc Fee

Essential Nexus

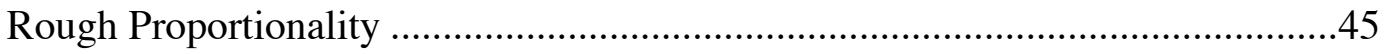

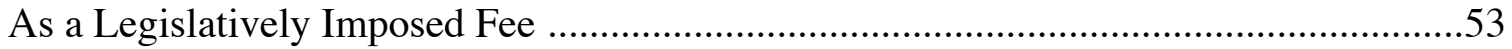

Use Of Fees-Impact of Development Connection..................................................54

Amount of Fees-Impact of Development Connection..........................................55

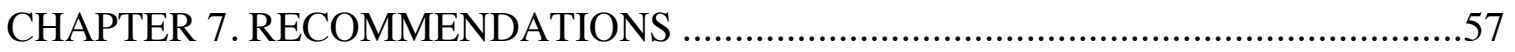

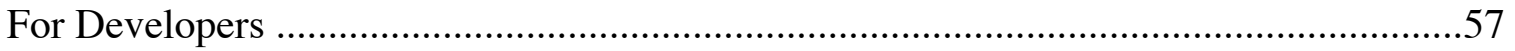

When Facing a CCC-required Ad Hoc Fee ..........................................................57

When Facing a Coastal Jurisdiction-adopted Legislatively Imposed Fee .............59

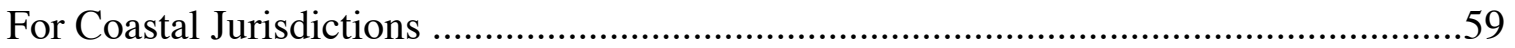

When Facing a CCC-Required Fee ...................................................................60

After Adoption of a CCC-Required Fee …………….........................................6

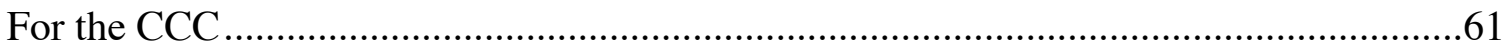

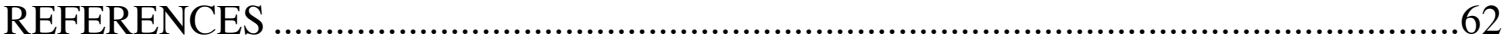




\section{LIST OF TABLES}

Table 1. Hypothetical Applications of the CCC In-Lieu Fee Trigger Formula ................18

Table 2. Summary of Case Study Findings ............................................................23

Table 3. Hypothetical Hotel Inventories for City A and City B ...................................50

Table 4. Hypothetical ADR Figures for City A and City B ........................................50

Table 5. Local Discretion in Adoption of the LCOVA In-Lieu Fee ................................56 


\section{LIST OF FIGURES}

Figure 1. Counties Within the California Coastal Zone .................................................

Figure 2. Expanded Equation for Local Low, Moderate, and High Cost Ranges .............16

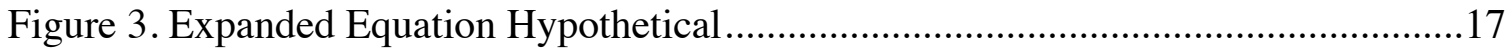

Figure 4. Diagram of Local Low, Moderate, and High Hotel Cost Ranges .....................17

Figure 5. Lee Court: Equations for Low, Moderate, and High Cost Ranges ....................32

Figure 6. Lee Court: Diagram of Local Low, Moderate, and High Cost Ranges..............32 


\section{Chapter 1. Background and Purpose}

Section 30213 of California Coastal Act requires the California Coastal Commission ("CCC") to protect, encourage, and, where feasible, provide for lower cost overnight visitor accommodations ("LCOVA") along the State's coast. ${ }^{1}$ As a mitigation measure per Section 30213, the CCC requires certain hotel and other development projects to include LCOVA facilities or pay an in-lieu fee. From 1977 to 2010, the CCC required over $\$ 16.7$ million for such in-lieu fees across 19 cases. $^{2}$

In 2006, the CCC conducted a workshop that studied hotel affordability along the California coast. The study showed that only 7.9 percent of hotels in the State's nine most popular costal counties were of low-cost. ${ }^{3}$ Given its charge to provide for LCOVA, the CCC revisited its related mitigation measure and in-lieu fees. Since 2006, the CCC has generally applied a three-prong approach (explained in detail in Chapter 2) that results in the imposition of a $\$ 30,000$ fee for 25 percent of hotel rooms determined to be higher cost (the “ $\$ 30,000 / 25 \%$ fee"). Generally, the CCC has imposed this fee in two circumstances:

1. Cal. Pub. Res. Code $\S 30213$. The California Coastal Act is codified in the Cal. Public Res. Code $\S \S 30000$, et seq.

2. California Coastal Commission, Status Report on In-Lieu Fee Mitigation for Impacts to Lower-Cost Overnight Accommodations, by Peter M. Douglas, Susan Hanscj, Charles Lester, Elizabeth A. Fuchs, Nicholas Dreher, F14c-5-2010, (San Francisco, CA, 2010), 1.

3 California Coastal Commission, South Coast Area Office, Major Amendment Request No. LOB-MAJ-1-10 (1-10) to the City of Long Beach Certified Local Coastal Program. For Public Hearing and Commission action at the Commission's June 16, 2011 Meeting in Marina del Ray, by John Ainsworth, Gary Timm, and Charles Posner, Th18a-6-2011, (Long Beach, CA, 2011), 33. This staff report concerns the Long Beach LCP Amendment, which is the second case study presented in Chapter 4 of this paper. 
1. Upon review of coastal development permit (“CDP”) applications, the CCC will require selected development projects to pay the $\$ 30,000 / 25 \%$ fee as a condition of permit approval.

2. Upon review of a local coastal program ("LCP") or related policy, the $\mathrm{CCC}$ will require that cities or other jurisdictions adopt and enforce the $\$ 30,000 / 25 \%$ fee.

Further, the CCC "has required mitigation for use of land that would have been available for lower cost and visitor serving facilities," meaning the CCC has imposed this fee for proposed hotel developments, whether or not they replace an existing low-cost hotel. ${ }^{4}$

The CCC's LCOVA mitigation policy and practices have surfaced as a contentious issue in coastal zone planning and development. At a July 10, 2014, CCC hearing, the imposition of a LCOVA mitigation measure drew critique from both the project applicant and CCC Commissioners. At issue was the Port of San Diego's Port Master Plan amendment accommodating construction of three hotels totaling 500 rooms along Harbor Island. ${ }^{5}$ In the project's staff report, the CCC staff recommended the following mitigation requirement:

A minimum of one-third (166 units) of the new 500 hotel rooms on East Harbor Island will be lower-cost overnight accommodations. As a special condition of the coastal development permit for any hotel development, redevelopment or change in lease that adds hotel rooms to East Harbor Island, the hotel developer will develop or designate its fair-share of on-site or off-site lower-cost overnight accommodations or pay an in-lieu fee based on a study conducted by the District that will designate the location and timeframe for construction of lower-cost accommodations within or adjacent to the District. An alternate location for the

4. $\quad$ Ibid., 32 .

5. $\quad$ Lori Weinberg, "Harbor Island Hotel Faces Delay," San Diego Union-Tribune, July 9, 2014, accessed July 25, 2014, http://www.utsandiego.com/news/2014/Jul/09/harbor-island-hotel-delayedcoastal-commission/ 
lower cost overnight accommodations required in this subarea may be considered through a future OMOA, pursuant to the results of the study. ${ }^{6}$

Facing the above requirement, the Port withdrew its application to amend its Port

Master Plan. The event was reported as follows:

As the coastal commissioners prepared to vote on the matter following a lengthy public hearing, a port official told the commissioners it was withdrawing its application. The unexpected request came as several commissioners expressed reservations about moving ahead on a project when there is no firm agreement on an affordable lodging policy.

"This has been a primary concern of mine as well," said Commissioner Martha McClure. "This is our third hotel development in the last year. For the commission to be 40 years old and not have a defined policy on this, we've come up short. We need a policy on this before we put it on the shoulder of developers." ${ }^{7}$

Despite the commissioner's sentiments, it is not entirely the case that the CCC

lacks a "defined policy" as to LCOVA mitigation. At the second of two public workshops conducted on this issue, ${ }^{8} \mathrm{CCC}$ Executive Director Charles Lester explained that the CCC's "policy" on this issue is defined by statute in Section $30213 .{ }^{9}$ Considering Lester's statement, perhaps commissioner's sentiments would be better attributed to the CCC's efforts to enforce the LCOVA mitigation policy. But according to the reporting above, the Port withdrew its application not because it viewed the would-be LCOVA

6. California Coastal Commission, San Diego Area Office, Staff Recommendation on San Diego Unified Port District Port Master Plan Amendment No. 46 (PMP-6-PSD-14-0002-6) East Harbor Island. For Commission consideration and possible action at the Meeting of July 9-11, 2014, by Sherilyn Sarb, Deborah Lee, Amanda Sackett, W18b-7-2014, (San Diego, CA, 2014), 22.

7. Weinberg, "Harbor Island Hotel Faces Delay."

8. California Coastal Commission, Public Workshop: Lower Cost Visitor Serving Accommodations Final Agenda (December 10, 2014), W3-12-2014, (San Francisco, CA, 2014); California Coastal Commission, Public Workshop: Lower Cost Visitor Serving Accommodations Final Agenda (March 13, 2014), F9-3-2015, (San Francisco, CA, 2015).

9. California Coastal Commission, Friday, March 13, 2015 9:00 A.M.: Public Workshop: Lower Cost Visitor Serving Accommodations (Video), Accessed April 15, 2015, Retrieved from http://www.cal-span.org/cgi-bin/archive.php?owner=CCC\&date=2015-03-13\&player=jwplayer\&captions= 
mitigation requirement was vague; the requirement was clear, but unacceptable to the Port. Further, the CCC's imposition of LCOVA in-lieu fees (i.e., the $\$ 30,000 / 25 \%$ fee) have been questioned as potentially inconsistent with standards governing such conditions.

The purpose of this paper is to explore the practice and legality of the CCC's application the $\$ 30,000 / 25 \%$ fee as a LCOVA mitigation measure. Broadly, this paper is composed of three parts: Policy analysis, legal analysis, and recommendations.

- $\quad$ Part 1. Policy Analysis: The first part (Chapters 2 through 4) explores the CCC's determination and application LCOVA mitigation policy and $\$ 30,000 / 25 \%$ fee. Chapter 2 provides a brief background on the CCC's establishment and organization as well as the development of the LCOVA mitigation policy. Chapter 3 dissects the CCC's approach to determine the $\$ 30,000 / 25 \%$ fee and examines its constituent comments. Chapter 4 identifies variation and flexibility of this approach across four case studies.

- $\quad$ Part 2. Legal Analysis: The second part (Chapters 5 and 6) considers the legality of the $\$ 30,000 / 25 \%$ fee. Chapter 5 discusses the Federal and California legal standards for review of in-lieu fees. Chapter 6 applies these standards to the $\$ 30,000 / 25 \%$ fee when required by CCC upon caseby case permit review and when imposed legislatively by jurisdictions as required by the $\mathrm{CCC}$. 
- $\quad$ Part 3. Recommendations: The third part (Chapter 7) recommends steps actions for developers and coastal jurisdictions considering the findings in the preceding chapters.

Ultimately, this paper concludes that the CCC's $\$ 30,000 / 25 \%$ fee likely fails the applicable legal standards and, unless the fee is revised, should be challenged or avoided by developers and jurisdictions. 


\section{Chapter 2. The CCC and LCOVA Mitigation Policy}

The CCC was first established in 1972 after California voters passed Proposition

20, and was made permanent by the state legislature in 1976 by adoption of the Coastal

Act. ${ }^{10}$ The CCC regulates land use and development and within the California Coastal

Zone. ${ }^{11}$ The Coastal Zone stretches across the state's coast and generally extends inland

1,000 yards. ${ }^{12}$ Shown in Figure 1 below, the 15 counties are included in the Coastal

Zone. $^{13}$

10. California Coastal Commission, "What We Do: Program Overview," last modified 2015, http://www.coastal.ca.gov/whoweare.html

11. Cal. Pub. Res. Code $\S 30103(a)$. “'Coastal zone' means that land and water area of the State of California from the Oregon border to the border of the Republic of Mexico, specified on the maps identified and set forth in Section 17 of that chapter of the Statutes of the 1975-76 Regular Session enacting this division, extending seaward to the state's outer limit of jurisdiction, including all offshore islands, and extending inland generally 1,000 yards from the mean high tide line of the sea. In significant coastal estuarine, habitat, and recreational areas it extends inland to the first major ridgeline paralleling the sea or five miles from the mean high tide line of the sea, whichever is less, and in developed urban areas the zone generally extends inland less than 1,000 yards. The coastal zone does not include the area of jurisdiction of the San Francisco Bay Conservation and Development Commission, established pursuant to Title 7.2 (commencing with Section 66600) of the Government Code, nor any area contiguous thereto, including any river, stream, tributary, creek, or flood control or drainage channel flowing into such area" (ibid.).

12. Ibid.

13. The 15 California counties boarding the coast (from north to south) are Del Norte, Humboldt, Mendocino, Sonoma, Marin, San Francisco, San Mateo, Santa Cruz, Monterey, San Luis Obispo, Santa Barbara, Ventura, Los Angeles, Orange, and San Diego. 


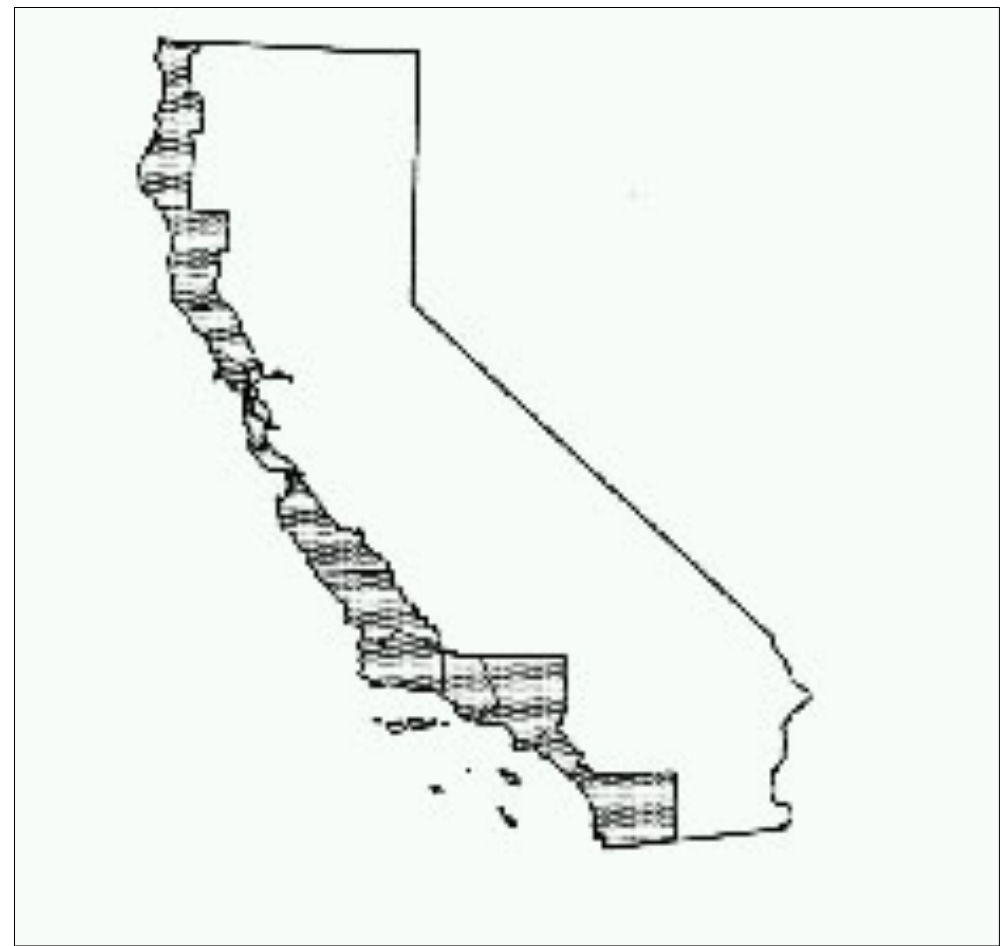

Figure 1. Counties Within the California Coastal Zone

Source: California Coastal Commission, "Permanent Responsibilities of the California Coastal Commission," last modified 2015, http://www.coastal.ca.gov/perresp.html

The CCC itself is comprised of 12 voting members and three non-voting members. ${ }^{14}$ The 12 voting members are appointed by the Governor, Senate Rules Committee, or the Speaker of the Assembly and include six local elected officials (e.g., city council members, county supervisors, etc.) and six members of the public. ${ }^{15}$ The three non-voting members include Secretaries of the Resources Agency, the Business and Transportation Agency, and the Chair of the State Lands Commission. ${ }^{16}$ The commission members are supported by an extensive staff lead by the Executive Director. ${ }^{17}$

14. California Coastal Commission, "Commissioners \& Alternates," last modified 2015, http://www.coastal.ca.gov/roster.html

15. Ibid.

16. Ibid.

17. California Coastal Commission, "Commissioner Biographies," last modified 2015, http://www.coastal.ca.gov/bios.html 
In exercising its functions, particularly review and issuance of CDPs and LCPs, the CCC effectuates its LCOVA mitigation policy. These functions and policy are described below.

\section{Functions of the CCC}

For purposes of this paper, the two most relevant functions of the CCC are to review and issue CDPs and to approve new and amended LCPs.

\section{Coastal Development Permits}

For development projects falling in the CCC's original jurisdiction (i.e., not covered by an LCP (discussed below)), the developer must apply to the CCC for a CDP. According to the CCC, "[p]ermit application review requires CCC staff to analyze the complete permit application and prepare a staff report including recommendations for Commission action. In addition, the CCC receives notice of all pending local coastal development permits." 18

\section{Local Coastal Programs}

Explained by the CCC, "Local Coastal Programs (LCPs) are basic planning tools used by local governments to guide development in the coastal zone, in partnership with the Coastal Commission." ${ }^{19}$ Once certified by the CCC, an LCP authorizes its municipality to issue coastal permits in a manner consistent with the Coastal Act and the

18. California Coastal Commission, "Procedural Guidance for the Review of Wetland Projects in California's Coastal Zone: Chapter 1 - Coastal Development Review Process,” last modified June 15, 1994, http://www.coastal.ca.gov/wetrev/wettitle.html

19. California Coastal Commission, "Local Coastal Programs (LCPs)," last modified 2015, http://www.coastal.ca.gov/lcps.html 
LCP. ${ }^{20}$ Sections 30500 , et seq. outline the substantive and procedural requirements for LCPs. ${ }^{21}$ The two major components of an LCP are a land use plan and an implementation plan. ${ }^{22}$ As discussed below, the LCPs must meet comply with the CCC's policy towards LCOVA set forth by Section 30213. ${ }^{23}$

\section{LCOVA Mitigation Policy}

The first sentence of the CCC's vision statement addresses the LCOVA issue:

The California coast is available for all to enjoy through thousands of public accessways to and along the shoreline, a completed California Coastal Trail, a well-supported network of parks and open spaces, and a wide range of visitorserving facilities, including lower-cost campgrounds, hostels, and hotels [Emphasis added]..$^{24}$

The CCC's power to regulate LCOVA is established in in the Coastal Act, but the Act also includes express statutory limitations to this power. ${ }^{25}$ The CCC exercises its regulatory authority in this realm by imposing the $\$ 30,000 / 25 \%$ fee among other tools. ${ }^{26}$ Below is a brief discussion of the statutes supporting and limiting the CCC's authority to regulate for LCOVA and the CCC's LCOVA mitigation toolbox.

20. California Coastal Commission, Local Coastal Program (LCP) Update Guide, (San Francisco, CA, 2013), 2.

21. Cal. Pub. Res. Code $\S \S 30500$, et seq.

22. California Coastal Commission, "Local Coastal Programs (LCPs)."

23. California Coastal Commission, Local Coastal Program (LCP) Update Guide, 2.

24. California Coastal Commission, California Coastal Commission Strategic Plan 20132018, (San Francisco, CA, 2013), 7.

25. The constitutional principle underlying the CCC's regulatory authority - the police power-is discussed in Chapter 5 of this paper.

26. The $\$ 30,000 / 25 \%$ fee is not expressly prescribed in the Coastal Act (Cal. Public Resources Code, $\S \S 3000$, et seq.) or in the Coastal Commission Regulations (Title 14 CCR, $\S \S 13001$, et seq.). The $\$ 30,000 / 25 \%$ fee and other LCOVA mitigation are practices by the CCC in an effort to effectuate the LCOVA mitigation policy set forth in Cal. Pub. Res. Code $\$ 30213$, discussed in this chapter. 


\section{Supporting Statutes}

The CCC finds its authority to impose LCOVA regulations in two sections of the Coastal Act -30213 and $30222 .{ }^{27}$ Each statute is explained below.

Section 30213

Section 30213 is the CCC's policy statement concerning LCOVA mitigation.

Section 30213 includes two paragraphs. The first paragraph, passed in 1976, grants the

CCC authority to take action on the LCOVA issue:

Lower cost visitor and recreational facilities shall be protected, encouraged, and, where feasible, provided. Developments providing public recreational opportunities are preferred. ${ }^{28}$

The second paragraph, passed in 1981 as an amendment to the statute, limits that authority:

The commission shall not: (1) require that overnight room rentals be fixed at an amount certain for any privately owned and operated hotel, motel, or other similar visitor-serving facility located on either public or private lands; or (2) establish or approve any method for the identification of low or moderate income persons for the purpose of determining eligibility for overnight room rentals in any such facilities. ${ }^{29}$

Initially, the CCC's actions under Section 30213 focused primarily on affordable housing development in the coastal zone.$^{30}$ The $\mathrm{CCC}$ also acted to regulate rates of new hotel and motel developments, "usually stipulate[ing] that some of the units be rented at

27. Discussed in Chapter 6 of this paper, $\S \S 30213$ and 30222 form the foundation of the legitimate state interest supporting the LCOVA in-lieu fee.

28. Cal. Pub. Res. Code $\S 30213$.

29. Ibid.

30. Paul A. Sabatier and Daniel A. Mazmanian, Can Regulation Work?: The Implementation of the 1972 California Coastal Initiative (New York, NY: Plenum Press, 1983), 332. 
reduced rates to people of moderate income." ${ }^{31}$ The 1981 amendment $^{32}$ responded to concerns that the CCC overreached in regulation of hotel development, and expressly prohibited the CCC from fixing room rates $^{33}$ and permitting income identification as a rate determinant.

Section 30222

Section 30222 further solidifies the CCC's authority to address the LCOVA issue by prioritizing visitor-serving uses over non-visitor serving uses along in the coastal zone:

The use of private lands suitable for visitor-serving commercial recreational facilities designed to enhance public opportunities for coastal recreation shall have priority over private residential, general industrial, or general commercial development, but not over agriculture or coastal-dependent industry. ${ }^{34}$

\section{The LCOVA Mitigation Toolbox}

The $\$ 30,000 / 25 \%$ fee is not the only tool the CCC employs in furtherance of the LCOVA mitigation policy. These tools are forms of exactions-requirements imposed by the government as conditions of approval for a development permit in order to offset or

31. Ibid., 333. "In a celebrated case involving two 300-unit hotels at Marine del Rey (Los Angeles), the commission accepted the owner's offer to reserve 45 rooms during weekends for low- and moderate-income people at no more than $50 \%$ of normal rates (with eligibility to be determined by guests' zip codes) in lieu of the commissions' more ambitious (and workable) proposal" (ibid.).

32. Ibid., 334. The 1981 amendment to $§ 30213$ (SB 1581) was sponsored by State Senator Alan Sieroty, a democrat representing District 22 (ibid.). In 1971, representing District 59 in the state assembly, Sieroty carried AB 1471 - the substantive precursor to the California Coastal Act (ibid., 39).

33. A potential issue may be whether or not the $\$ 30,000 / 25 \%$ fee constitutes rate fixing in violation of $\S 30213$. It could be argued that the $\$ 30,000 / 25 \%$ fee functions as a de-facto cap on room rates, in that the fee may discourage higher hotel room rates or incentivize lower hotel room rates. However, such results are likely not tantamount to the fixing of room rates, because the $\mathrm{CCC}$ is not strictly forbidding rates above or below a singular price point.

34. Cal. Pub. Res. Code $\$ 30222$. 
mitigate public harms created by the development. ${ }^{35}$ As a condition for approval, the government may either exact property (a property exaction) or money (a monetary exaction $^{36}$ ) from the applicant.

The CCC's LCOVA mitigation property exaction tool is the on-site LCOVA facility development requirement. In a number of cases, the $\mathrm{CCC}$ required hotel developers to build a tent campground on-site to mitigate the perceived limited affordability of the hotel development. ${ }^{37}$ The $\$ 30,000 / 25 \%$ fee, the subject of this paper, is the CCC's monetary exaction tool in LCOVA mitigation toolbox.

35. The federal and California legal standards governing exactions are discussed in Chapter 6 of this paper.

36. The two types of monetary exactions, ad hoc fees and legislatively imposed fee, are discussed in Chapter 6 of this paper.

37. Public Workshop: Lower Cost Visitor Serving Accommodations (December 10, 2014), 16-17. Cases where the CCC required on-site mitigation include: "1) Appeal No. A 71-78 for the City of Long Beach Convention Hotel resulted in 70 RV camping sites at the Golden Shore RV Resort. 2) Appeal No. 55-80 for Lifetime Communities/Santa Catalina Island Company resulted in 120 camping sites at Hermit Gulch Campground on Catalina Island. 3) CDP 3-82-171 for the Ventana Inn in Big Sur resulted in 100 camping sites at Ventana Campground. 4) Appeal No. A-3-SMC-89-063 for Gould, San Mateo County resulted in 112 RV sites and 76 tent camping sites at Costanoa, just south of Pigeon Point Lighthouse" (ibid). 


\section{Chapter 3. LCOVA In-Lieu Fee Formulation}

The CCC generally applies the following three-pronged approach to formulate the LCOVA in-lieu fee:

1. Define local lower, moderate, and higher cost rates,

2. Determine the per room in-lieu fee, and

3. Establish an in-lieu fee account.

This approach generally results in the CCC imposing the $\$ 30,000 / 25 \%$ fee. This chapter dissects the above approach and explains its constituent elements. As discussed in Chapters 1 and 2, the CCC has imposed the $\$ 30,000 / 25 \%$ fee in review of development permits as well as LCP and related policies. The CCC has not applied the three-prong approach uniformly across all cases. Chapter 4 delves into and highlights key variations in application of the three-prong approach.

\section{Defining Local Low, Moderate, and High Cost Rates}

In the past, the CCC generally considered a LCOVA hotel as one that charges $\$ 100$ or less per room per night. ${ }^{38}$ First applied in the Ventura LCP Amendment case in 2008 , the CCC now uses a formula to calculate three ranges of hotel costs - low, moderate, and high — in the relevant region. ${ }^{39}$ These ranges are based on the statewide

38. California Coastal Commission, San Diego Area Office, Addendum to Item Th16e, Coastal Commission Permit Application \#6-13-0407 (McMillin-NTC, LLC), for the Commission Meeting of February 13, 2014, Th16e-2-2014 (San Diego, CA, 2014), 29. This staff report includes revised findings concerning the 2200 Lee Court Project in San Diego, CA, the fourth case study presented in this Chapter 4 of this paper.

39. LOB-MAJ-1-10 (1-10) City of Long Beach, 33. "More recent Commission actions have utilized a formula that can be used to determine low and high cost overnight accommodations for a specific part of the coast [SBV-MAJ-2-08 \& 5-98-156-A17]" (ibid). 
average daily rate ("ADR") of California hotels. Discussed in further detail below, the formula involves three steps:

1. Determine the statewide ADR,

2. Set the geographic zone of local hotels surveyed, and

3. Identify the low, moderate, and high-cost ranges in the relevant local area.

The CCC's in-lieu fee is triggered at the high-cost range. As noted below, the

CCC considers some types of overnight accommodations to be "inherently lower cost" (i.e., LCOVA facilities):

The formula is based on California hotel and motel accommodations (single room, up to double occupancy), and does not incorporate hostels, RV [recreation vehicle] parks, campgrounds or other alternative accommodations into the equation, as these facilities do not provide the same level of accommodation as hotels and motels. Hostels, RV parks, and campgrounds are inherently lower cost, and are the type of facilities that a mitigation charge for the loss of affordable overnight accommodations would support. ${ }^{40}$

The CCC has recently reconsidered whether RV parks are "inherently low cost." RV parks 2014 CCC staff report explains that RV sites may not always constitute LCOVA facilities after accounting for the cost of purchasing and maintaining the RV itself. ${ }^{41}$

\section{Determine Statewide Hotel Average Daily Rate}

In 2007, the CCC obtained the statewide ADR from Smith Travel Research (“STR") trend reports within the following parameters.

1. The survey included California hotels and motels (here, referred to collectively as "hotels") participating in STR's trend surveys, ${ }^{42}$ and

40. South Coast Area Office, LOB-MAJ-1-10 (1-10) City of Long Beach, 33.

41. California Coastal Commission, Public Workshop: Lower Cost Visitor Serving Accommodations (December 10, 2014), 9-10. 
2. The CCC used peak season (July and August) average monthly ADR ${ }^{43}$

Based on the STR data, ${ }^{44}$ the CCC determined the statewide ADR to be $\$ 132.90$ at peak season in $2007 .{ }^{45}$ The CCC still relies on the 2007 statewide ADR in some cases today. According the CCC, the 2007 figure remains valid because the statewide ADR has experienced little fluctuation since 2007 - falling by $\$ 3.97$ from 2007 to $2013{ }^{46}$

Geographic Zone of Local Hotels Surveyed

With the statewide ADR determined, the CCC builds an inventory of local hotels to survey. There are two steps to building the inventory. First, the CCC sets the geographic zone for hotels. This zone two characteristics:

1. The political boundary (the city or county), and

2. The distance from the coastline (the California Coastal Zone or five miles from the coastline (the "Five Mile Zone")).

The case studies in Chapter 4 will show that the CCC has varied in its application of these characteristics. Second, the CCC generally applies the following parameters to arrive at a list of hotels within the zone:

1. The CCC only surveys AAA Auto Club rated properties to ensure an acceptable level of quality, and

42. Ibid.

43. Ibid.

44. Interview with Smith Travel Research Trends Department Staff, August 21, 2014. The hotels included in the STR trend reports are typically of 10 rooms or more.

45. San Diego Area Office, 6-13-0407 (McMillin-NTC, LLC), 30.

46. Ibid., 29-30. 
2. The CCC considers rates during peak season (July and August). ${ }^{47}$

The second parameter, considering rates during the peak season, is consistent with the statewide ADR parameters, but the first parameter-including only AAA-rated properties - is not consistent with the statewide ADR parameters.

Identify the Local Low, Moderate, and High Cost Ranges

Using the statewide and local ADR data, the CCC identifies the local low, moderate, and high-cost ranges using the following equations:

The CCC considers the aggregated ADR for local hotels that fall below the statewide ADR (the "Local Low ADR"). ${ }^{48}$ The Local Low ADR is divided by the Statewide ADR to generate, what this paper refers to as, the Local ADR Quotient. 1 minus the Local ADR Quotient calculates a range ("Cost Range”) applied above and below the Statewide ADR to identify the lower, moderate, and higher cost ranges.

To better illustrate the CCC's process described above, an expanded equation is shown in Figure 2.

Statewide ADR = Determined by the CCC survey Local Low ADR = Local ADR for hotels surveyed with ADRs lower than the Statewide ADR Local ADR Quotient = Local ADR / Statewide ADR

Cost Range $=(1-$ Local ADR Quotient $) *$ Statewide ADR

Local High Cost Point $=$ Statewide ADR + Cost Range

Local Low Cost Point $=$ Statewide ADR - Cost Range and $=$ Local Low ADR

Local Low Cost Range < Local Low Coast Point

Local Moderate Cost Range $\geq$ Local Low Cost Point and $\leq$ Local High Cost Point

Local High Cost Range > Local High Cost Point

Figure 2. Expanded Equation for Local Low, Moderate, and High Cost Ranges

47. South Coast Area Office, LOB-MAJ-1-10 (1-10) City of Long Beach, 33.

48. San Diego Area Office, 6-13-0407 (McMillin-NTC, LLC), 31. 
The equation in Figure 2 shows more steps than presented in CCC staff reports, but the additional steps are mathematically consistent with the CCC's process. Figure 3 below shows the expanded equations using hypothetical values of $\$ 100$ for the Statewide ADR and $\$ 90$ for the Local Low ADR.

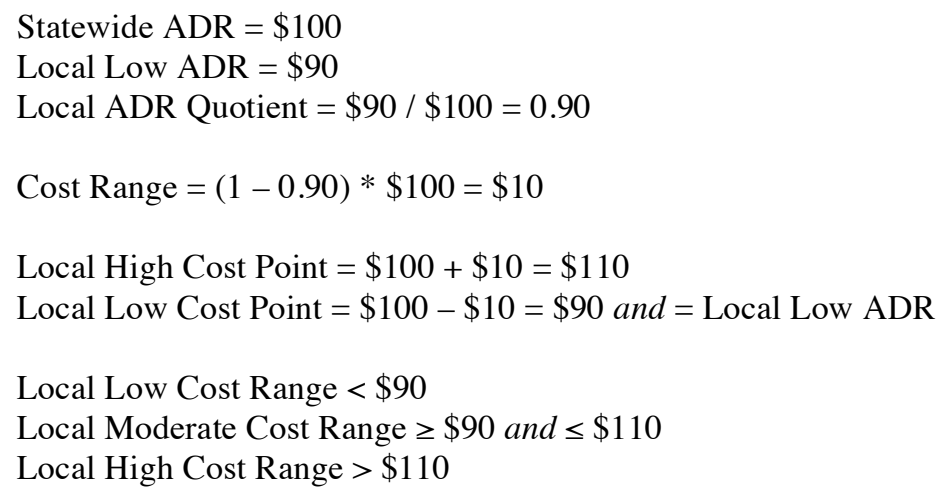

Figure 3. Expanded Equation Hypothetical

The expanded equation serves two purposes:

- $\quad$ Allows the CCC's process to be diagrammed in Figure 4, and

- $\quad$ Clearer comparison in its application across case studies in Chapter 4.

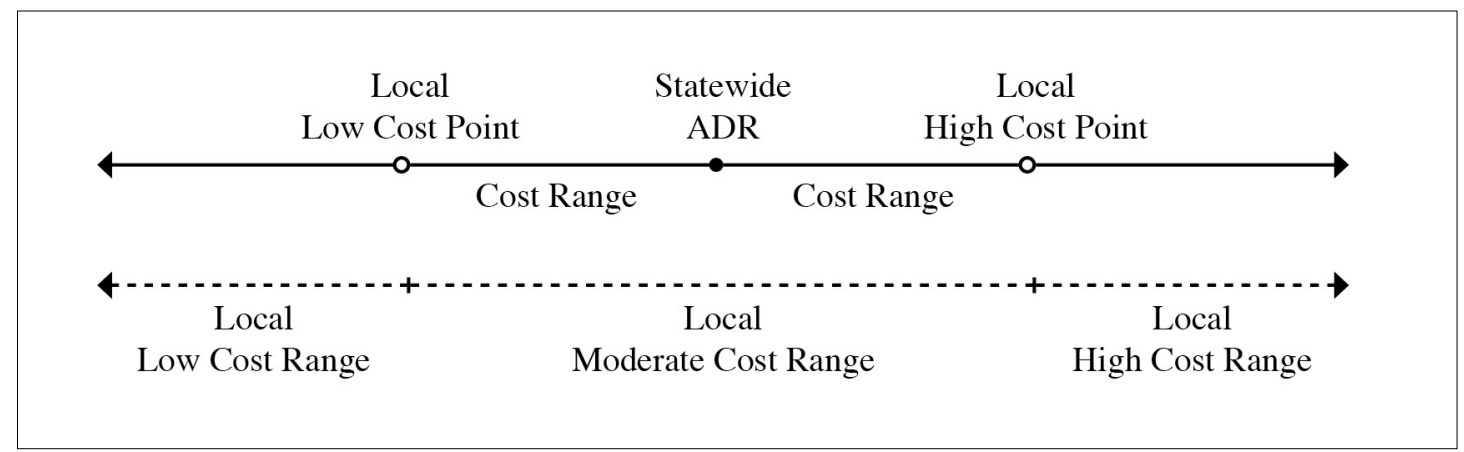

Figure 4. Diagram of Local Low, Moderate, and High Hotel Cost Ranges 
The CCC's trigger for imposing in-lieu fees is the Local High Cost Range-rates above the Local High Cost Point. ${ }^{49}$ Table 1 below demonstrates this formula's results from hypothetical proposed hotels:

Table 1. Hypothetical Applications of the CCC In-Lieu Fee Trigger Formula

\begin{tabular}{|c|c|c|c|c|c|}
\hline \multicolumn{3}{|c|}{ Hypothetical Hotel Data } & \multirow{2}{*}{$\begin{array}{c}\text { July and August } \\
2013 \text { Statewide } \\
\text { ADR }\end{array}$} & \multirow[b]{2}{*}{ Cost Range } & \multirow{2}{*}{$\begin{array}{l}\text { Local High Cost } \\
\text { Range (In-Lieu } \\
\text { Fee Trigger) }\end{array}$} \\
\hline Proposed Hotel & Local ADR & $\begin{array}{c}\text { Local Low } \\
\text { ADR }\end{array}$ & & & \\
\hline Hotel A & $\$ 125.00$ & $\$ 90.00$ & \multirow{4}{*}{$\$ 128.93$} & $\$ 38.93$ & $>\$ 167.86$ \\
\hline Hotel B & $\$ 130.00$ & $\$ 100.00$ & & $\$ 28.93$ & $>\$ 157.86$ \\
\hline Hotel C & $\$ 150.00$ & $\$ 110.00$ & & $\$ 18.93$ & $>\$ 147.86$ \\
\hline Hotel D & $\$ 140.00$ & $\$ 120.00$ & & $\$ 8.93$ & $>\$ 137.86$ \\
\hline
\end{tabular}

There is an inverse relationship between the Local Low ADR and the Local High Cost Range (the in-lieu fee trigger). Hotels in areas with lower Local Low ADRs will have a higher Local High Cost Range, meaning that the in-lieu fee is triggered at a higher rate. As discussed in the section below, the CCC typically imposes the $\$ 30,000 / 25 \%$ fee. For example, Hotel A is proposed for an area with a Local Low ADR of \$90.00. Based on the formula, Hotel A's developers would pay $\$ 30,000$ for 25 percent of rooms with rates greater than $\$ 167.86$. Hotel $\mathrm{B}$, proposed in an area with a Local Low ADR of $\$ 110.00$ would trigger the in-lieu fee for rooms with rates greater than $\$ 157.86$. A higher High Cost Point likely means that fewer rooms will be penalized by the in-lieu fee.

The overall ADR for the local area is not a factor in the formula. Consider the following: Hotel C and Hotel D are proposed in areas with respective Local ADRs of $\$ 150.00$ and $\$ 140.00$. However, because Hotel C's area's Local Low ADR is lower than that of Hotel D's area, Hotel C's in-lieu fee is triggered at a higher point.

49. California Coastal Commission, South Coast Area Office, Staff Report: Regular Calendar, Application No.: 5-13-0717, Applicant: 1429 Hermosa, LLC, F10a-6-2014 (Long Beach, CA, 2014), 18. This staff report addressed the permit application for a proposed 30-room boutique hotel to be constructed at 1429 Hermosa Avenue, Hermosa Beach, CA. 
Further, because the equation only considers the ADR of local hotels below the statewide ADR, the equation will in theory always produce a Local High Cost Point. Therefore, the equation will always trigger an in-lieu fee. Hotel A is proposed in an area with a Local ADR below the statewide average, but the formula still triggers an in-lieu fee for the development.

\section{Determining the Per Room In-lieu Fee}

In a number of decisions, the CCC imposed the $\$ 30,000 / 25 \%$ fee $(\$ 30,000$ for $25 \%$ of rooms) for hotel projects' room rates that fall in the Local High Cost Range. ${ }^{50}$

The CCC derived the $\$ 30,000$ figure from information provided to the CCC by

Hostelling International ("HI") in a letter dated October 26, 2007. ${ }^{51}$ The CCC explains:

The figures provided by HI are based on two models for a 100-bed, 15,000 sq. ft. hostel facility in the Coastal Zone. The figures are based on experience with the existing 153-bed, HI-San Diego Downtown Hostel. Both models include construction costs for rehabilitation of an existing structure. The difference in the two models is that one includes the cost of purchase of the land and the other is based on operating a leased facility. Both models include "Hard" and "Soft Costs" and startup costs, but not operating costs. "Hard" costs include, among other things, the costs of purchasing the building and land and construction costs (including a construction cost contingency and performance bond for the contractor). "Soft" costs include, among other things, closing costs, architectural and engineering costs, construction management, permit fees, legal fees, furniture and equipment costs and marketing costs. Based on these figures, the total cost per bed for the two models ranges from $\$ 18,300$ for the leased facility to $\$ 44,989$ for the facility constructed on purchased land. ${ }^{52}$

\footnotetext{
50. South Coast Area Office, LOB-MAJ-1-10 (1-10) City of Long Beach, 35.

51. San Diego Area Office, 6-13-0407 (McMillin-NTC, LLC), 33.

52. Ibid.
} 
The CCC arrived at the $\$ 30,000$ amount by taking the rough average between the per bed costs in the two models ${ }^{53}$ In some cases, the CCC adjusts the fee to inflation. ${ }^{54}$ From a review of case studies, Section 3 will show that there is some flexibility in application of the $\$ 30,000 / 25 \%$ fee.

\section{Establishing an In-Lieu Fee Account}

Finally, the CCC then requires the creation of an interest-bearing account to hold the in-lieu fees. ${ }^{55}$ The fees are to be distributed as "grants to public agencies or non-profit organizations for the provision of LCOVA facilities within or in close proximity to the coastal zone." 56

In past actions, the CCC allowed the jurisdiction (e.g., the applying city) to select from a list of entities to manage the account.$^{57}$ The CCC Executive Director must approve the selection. These options have included:

- $\quad$ The jurisdiction itself,

- Hostelling International USA,

- California State Coastal Conservancy,

- California Department of Parks and Recreation, or

53. California Coastal Commission, South Central Coast Area Office, Agenda Items 11a and 11b, City of San Buenaventura Local Coastal Program (LCP) Amendment SBV-MAJ-1-08 [Midtown Corridor Development Code-Main Street and Thompson Boulevard] and SBV-MAJ-2-08 [Downtown Specific Plan] for Public Hearing and Commission Action at the California Coastal Commission hearing of November 5, 2009 in Long Beach, Th11a-11-2009 (Ventura, CA, 2009), 28. The City of Buenaventura is also known as the City of Ventura. This staff report concerns the first case study presented in Chapter 4 of this paper.

54. South Coast Area Office, 5-13-0717, 1429 Hermosa, LLC, 18.

55. Ibid.

56. Ibid.

57. Ibid., 9 . 
- A similar entity. ${ }^{58}$

A management plan for the account must be reviewed and approved by the CCC Executive Director. The management plan must include:

- Details of how deposits into the account will be processed,

- Investment strategies to ensure a reasonable rate of return, and

- $\quad$ Guidelines for how grants for LCOVA facilities will be managed (i.e., applications, selection process, oversight). ${ }^{59}$

There is some conflicting information regarding establishment of these accounts when required through an LCP update or similar application. CCC staff reports suggest that one account would be created to hold in-lieu fees for subsequent projects approved under the LCP.

58. Ibid., 18 .

59. Ibid., 9-10. 


\section{Chapter 4. Case Studies}

Chapter 3 identified and detailed the CCC's three-prong approach for formulating the LCOVA in-lieu fee. This chapter reviews four case studies that highlight incidents of flexibility and variance by the $\mathrm{CCC}$ in applying this approach:

- $\quad$ City of Ventura, LCP Amendment (2008): This case represents the first instance where the CCC applied the three-prong approach. Further, this case highlights the CCC's possible openness to consider an alternative approach.

- $\quad$ City of Long Beach, LCP Amendment (2010): This case features two notable deviations from CCC's standard approach by using a small sample of hotels as the local inventory in a select part of the coast line and relying on another jurisdiction's data to set the in-lieu fee trigger.

- $\quad$ City of Solana Beach, LCP Land Use Plan (2012): In this case, the CCC delegated much of the local hotel inventory data procurement and cost range determination to the local jurisdiction.

- $\quad$ City of San Diego, 220 Lee Court Project (2014): Unlike the other three cases, this case study regards an individual development project. This case is of interest because the CCC exercised considerable flexibility in its determination of the per-room in-lieu fee.

The case studies are structured by its three-prong approach to the LCOVA in-lieu fee. Table 2 provides a summary of the findings: 
Table 2. Summary of Case Study Findings

\begin{tabular}{|c|c|c|c|}
\hline $\begin{array}{l}\text { City of Ventura, LCP } \\
\text { Amendment (2008) }\end{array}$ & $\begin{array}{l}\text { City of Long Beach, } \\
\text { LCP Amendment } \\
(2010)\end{array}$ & $\begin{array}{l}\text { City of Solana Beach, } \\
\text { LCP Land Use Plan } \\
(2012)\end{array}$ & $\begin{array}{c}\text { City of San Diego, } \\
2200 \text { Lee Court Project } \\
(2014)\end{array}$ \\
\hline \multicolumn{4}{|c|}{ Defining Local Low, Moderate, and High Cost Hotel Rates } \\
\hline $\begin{array}{l}\text { Standard formula } \\
\text { applied to hotels in the } \\
\text { City of Ventura } \\
\text { Coastal Zone. }\end{array}$ & $\begin{array}{l}\text { Three variations: (1) } \\
\text { only considered } \\
\text { downtown coastline, } \\
\text { (2) used a sampling of } \\
\text { hotels, and (3) relied } \\
\text { on comparisons to City } \\
\text { of Ventura. }\end{array}$ & $\begin{array}{l}\text { The CCC delegated } \\
\text { accounting of hotel } \\
\text { cost ranges to the City, } \\
\text { stating that a suitable } \\
\text { method would include } \\
\text { an inventory of hotels } \\
\text { in San Diego County } \\
\text { within the Five Mile } \\
\text { Zone. }\end{array}$ & $\begin{array}{l}\text { The CCC included two } \\
\text { variations to the } \\
\text { standard formula for } \\
\text { the Statewide ADR and } \\
\text { the Local High Cost } \\
\text { Point. The relevant } \\
\text { area included hotels in } \\
\text { San Diego County } \\
\text { within the Five Mile } \\
\text { Zone. }\end{array}$ \\
\hline \multicolumn{4}{|c|}{ Determining the Per Room In-Lieu Fee } \\
\hline $\begin{array}{l}\$ 30,000 / 25 \% \text { fee } \\
\text { applied, however the } \\
\text { CCC shows some room } \\
\text { for flexibility. }\end{array}$ & $\begin{array}{l}\$ 30,000 / 25 \% \text { fee } \\
\text { applied, with two } \\
\text { exceptions: }(1) \$ 1.5 \\
\text { million fee for a } \\
\text { specific project and (2) } \\
\text { provided an alternative } \\
\text { mitigation to the } \\
\$ 30,000 / 25 \% \text { fee. }\end{array}$ & $\begin{array}{l}\$ 30,000 / 25 \% \text { fee } \\
\text { applied, but adjusted } \\
\text { for inflation. }\end{array}$ & $\begin{array}{l}\text { The CCC imposed a } \\
\$ 30,000 / 12.5 \% \text { fee } \\
\text { given the } \\
\text { development's } \\
\text { proposed free } \\
\text { amenities and } \\
\text { accommodation of } \\
\text { rooms for more guests. }\end{array}$ \\
\hline \multicolumn{4}{|c|}{ Establishing an Account to Hold and Distribute In-Lieu Fees } \\
\hline $\begin{array}{l}\text { The City has yet to } \\
\text { collect any in-lieu fees } \\
\text { or establish an account. }\end{array}$ & $\begin{array}{l}\text { Standard language on } \\
\text { account creation. }\end{array}$ & $\begin{array}{l}\text { According to City } \\
\text { policy, the City will } \\
\text { create and manage the } \\
\text { account, but has yet to } \\
\text { do so. }\end{array}$ & $\begin{array}{l}\text { No direct call for } \\
\text { creation of an account }\end{array}$ \\
\hline
\end{tabular}

\section{City of Ventura, LCP Amendment (2008)}

In 2008, The City of Ventura submitted an amendment to its LCP to the CCC for approval. As mentioned earlier, this case was the first instance in which CCC used the formula to determine low, moderate, and high-cost categories for hotel rooms in a particular locale.$^{60}$ 
Defining Local Low, Moderate, and High Cost Rates

The CCC applied the three-step formula as described in Chapter 3. For the second step, defining the geographic zone of local hotels for survey, the CCC used City of Ventura as the political boundary and "the City of Ventura Coastal Zone" for the distance from the coastline.$^{61}$ The staff report did not further specify distance from the coastline. The Higher Cost Point was subsequently defined as 25 percent of the statewide ADR. ${ }^{62}$

\section{Determining the Per Room In-Lieu Fee}

To receive approval for the LCP amendment, the CCC recommended that Ventura include the $\$ 30,000 / 25 \%$ mitigation measure to provide for low-cost lodging. ${ }^{63}$ Opposed to the broader general application of the $\$ 30,000 / 25 \%$ fee above, Ventura requested, and the CCC agreed to consider, that an alternative local threshold be applied. However, according to a CCC staff report, Ventura staff failed to come forth with an alternative. ${ }^{64}$

\section{Establishing an In-Lieu Fee Account}

According to City of Ventura staff, Ventura has yet to collect any LCOVA in-lieu fees from coastal development under the approved amendment and has not established an account for this purpose. ${ }^{65}$
61. South Central Coast Area Office, City of San Buenaventura SBV-MAJ-2-08, 20.
62. Ibid., 21.
63. Ibid., 3-4.
64. Ibid.
65. Interview with City of Ventura, Community Development Department Staff, July 24, 2014. 
City of Long Beach, LCP Amendment (2010)

In 2010, the City of Long Beach submitted to the CCC an amendment to the City's LCP. The amendment concerned one designated area of the LCP: Downtown Shoreline Planned Development District (PD-6). The purpose of the amendment was to incorporate into PD-6 the Golden Shore Master Plan - a development project featuring new hotel construction. ${ }^{66}$

Defining Local Low, Moderate, and High Cost Rates

In this case, the CCC strayed from the formula applied in the Ventura case in three ways:

1. Considering hotels in only one area of Long Beach's coastline,

2. Drawing only a sample of hotels from that area, and

3. Relying on a comparable city's (Ventura) data instead of applying the formula to Long Beach hotels. These variations are explained further below.

First, the CCC looked at hotels within the Downtown Shoreline area ${ }^{67}$ This is a relatively narrower area than that used in the Ventura case (Coastal Zone the City of Ventura).

Second, the CCC considered only a sample of hotels in this area, explaining that “[a] similar comprehensive study [referencing the Ventura case] of all the hotels in Long Beach has not been conducted, although a sampling (2009) of the hotels in or near the

66. South Coast Area Office, LOB-MAJ-1-10 (1-10) City of Long Beach, 1.

67. Ibid., 34 . 
Downtown Shoreline area has been done." ${ }^{68}$ The CCC staff report did not expand on the parameters. Based on this review, the CCC found that there are no affordable hotels within the Downtown Shoreline area. ${ }^{69}$

Third, to determine the low, moderate, and high cost ranges, the CCC did not apply its formula to the sample drawn of Long Beach hotels in the Downtown Shoreline area. Instead, it relied on figures from the Ventura case. As explained in the CCC staff report:

The hotel room rates in Long Beach are similar to Ventura's rates. Therefore, the definition of low cost accommodations in Long Beach will be defined (for the suggested modification pertaining to Subarea 1a) as those charging less than seventy-five percent (75\%), or twenty- five percent (25\%) below, the statewide average daily room rate during peak season. ${ }^{70}$

Like in the Ventura case, the local High Cost Point in the Long Beach Case was subsequently defined as 25 percent greater than the statewide ADR. ${ }^{71}$

Determining the Per Room In-Lieu Fee

The CCC applied the $\$ 30,000 / 25 \%$ fee in the Long Beach case ${ }^{72}$ with two exceptions.

The first exception is specific to the first to phases of the Golden Shore Master Plan:

A new hotel, with at least one hundred rooms, shall be provided as part of the first or second phase of the implementation of the Golden Shore Master Plan, or a

68. Ibid.

69. Ibid.

70. Ibid.

71. Ibid.

72. Ibid., 30, 36 . 
mitigation charge of $\$ 1.5$ million shall be paid by the applicant into an interestbearing account, to be established and managed by the City of Long Beach. ${ }^{73}$

The CCC explained that "[t]he $\$ 1.5$ million mitigation charge is equivalent to the cost of a new 82-bed hostel (at $\$ 18,300$ a bed) on leased land." ${ }^{74}$ This diverges from the CCC's practice in other cases in two respects: First, as described earlier in this paper, the CCC arrived at the $\$ 30,000$ figure by taking the rough average between " $\$ 18,300$ for the leased [hostel] facility" and " $\$ 44,989$ for the [hostel] facility constructed on purchased land. ${ }^{75}$ Second, the $\$ 1.5$ million is a lump sum that is not tied to a particular portion of rooms.

In the second exception, the CCC staff report provides an alternative mitigation method:

As an alternative to the payment of the mitigation charge, and as an alternative to providing lower cost overnight visitor accommodations within Sub-area 1a of PD6 (Golden Shore Master Plan Site), the applicant may, subject to review and approval by the City Planning Commission and/or City Council, provide for the completion of a specific project (e.g., a youth hostel) that provides lower cost overnight visitor accommodations at a minimum ratio of one (1) bed for each new hotel room constructed on the Golden Shore Master Plan site that does not qualify as a "lower cost" visitor room. The applicant's specific project shall provide a minimum of one hundred (100) beds - up to a maximum of two hundred (200) beds. The alternative project shall be located within the City of Long Beach coastal area, defined as the area within one-half mile of the inland boundary of the City's coastal zone. ${ }^{76}$

\section{Ibid., 29.}

74. Ibid.

75. South Coast Area Office, 5-13-0717, 1429 Hermosa, LLC, 33. This description is also provided in the CCC Staff Report for the Long Beach case at LOB-MAJ-1-10 (1-10) City of Long Beach, 36.

76. South Coast Area Office, LOB-MAJ-1-10 (1-10) City of Long Beach, 30. 
Establishing an In-Lieu Fee Account

The CCC staff report did not expand beyond the standard language described earlier in this paper. ${ }^{77}$

City of Solana Beach, LCP Land Use Plan (2012)

In 2012, the CCC reviewed the City of Solana Beach's Local Coastal Plan Land Use Plan ("LCP LUP"). ${ }^{78}$ The Land Use Plan is a component of the Local Coastal Plan that specifies location and type of land and water uses in the Local Coastal Plan area. An LCP LUP may also contain strategies and policies that represent local conditions, goals and interests.

Defining Local Low, Moderate, and High Cost Rates

In the Solana Beach case, the CCC delegated much of the lower cost hotel definition process to the City's LCP LUP. In the Ventura case discussed above and the 2200 Lee Court case in San Diego discussed later, CCC staff performed these calculations. The CCC approved the following language for Policy 2.33 of Solana Beach's LCP LUP:

The City shall maintain an accounting of the number of existing motel and hotel rooms and room rates. When referring to overnight accommodations, lower cost shall be defined by a certain percentage of the Statewide average room rate as calculated by the Smith Travel Research website (www.visitcalifornia.com) or other comparable or similar website or study such as www.Calif.AAA.com. A suitable methodology would base the percentage on market conditions in San Diego County for the months of July and August and include the average cost of

77. Ibid., 31 .

78. California Coastal Commission, San Diego Area Office, Revised Findings on City of Solana Beach LCP Land Use Plan for Commission Meeting of June 13-15, 2012, by Sherilyn Sarb, Deborah Lee, and Diana Lilly, Th24a-6-2012 (San Diego, CA, 2012), 1. 
motels/hotels within five (5) miles of the coast that charge less than the Statewide average. High cost would be room rates that are $20 \%$ higher than the Statewide average, and moderate cost room rates would be between high and low cost. The range of affordability of new and/or replacement hotel/motel development shall be determined as part of the coastal development permit process and monitored as part of the City's inventory of overnight accommodations. ${ }^{79}$

This language presents two major variations from the standard approach modeled in the Ventura case.

First, concerning the geographic zone of local hotels for survey, the CCC used San Diego County as the political boundary and "five (5) miles of the coast" as distance from the coastline. ${ }^{80}$ The Ventura case also involved an update to city policy, but cast a narrower political boundary surveying hotels within the city jurisdiction not the entire county. ${ }^{81}$ Also, the Ventura case used the Coastal Zone ${ }^{82}$ within the City for distance from the coastline, while the Solana Beach case specified five miles from the coast. Aside from difference in land area, varying zones will produce local hotel inventories with different price points and other characteristics.

Second, the staff report for Solana Beach seems to not apply directly the low-cost formula to a sample of hotels in the determined relevant area. In this case, the CCC defines higher-cost hotel rooms as 20 percent above the State average, but that the "range of affordability of new and/or replacement hotel/motel development" will be determined on an on-going permit-by-permit basis. ${ }^{83}$

\footnotetext{
79. Ibid., 11.

80. Ibid.

81. South Central Coast Area Office, City of San Buenaventura SBV-MAJ-2-08, 20.

82. Cal. Pub. Res. Code $\S 30103(a)$.

83. San Diego Area Office, Findings on Solana Beach LCP Land Use Plan, 11.
} 


\section{Determining the Per Room In-Lieu Fee}

For Solana Beach, the CCC applied the $\$ 30,000 / 25 \%$ fee, but adjusted for inflation. The staff report states, "This payment (i.e. $\$ 30,000$ in 2007) is to be adjusted annually to account for inflation according to increases in the Consumer Price Index U.S. City Average. ${ }^{\circledR 4}$

Establishing an In-Lieu Fee Account

According to City staff, Solana Beach has yet to adopt a local implementation program or LCP, and therefore the City has not established its in-lieu fee account. However, the CCC approved the following language for Policy 5.8 in the City's LCP LUP concerning the account:

The required monies [from the LCOVA in-lieu fees] shall be deposited into an interest-bearing account, to be established and managed by the City of Solana Beach. The purpose of the account shall be to establish lower cost overnight visitor accommodations within the City of Solana Beach as the first priority or elsewhere in North San Diego County coastal area as a second priority. The monies and accrued interest shall be used for the above-stated purpose, in consultation with the CCC Executive Director. Any development funded by this account will require review and approval by the Executive Director of the Coastal Commission and a coastal development permit. ${ }^{85}$

\section{City of San Diego, 2200 Lee Court Project (2014)}

The 2200 Lee Court Project, proposed by McMillin-NTC, LLC, is located in San Diego's Liberty Station. Unlike in the Ventura and Solana Beach case studies, which each involved updates to a city's LCP, 2200 Lee Court is an individual development
84. Ibid., 88-89.
85. Ibid., 51. 
project pursued by a private developer. The site was formerly a US Naval Training Center under jurisdiction of the federal government, but was later transferred to City of San Diego in a public trust. ${ }^{86}$ Despite certification of an LCP for the Naval Training Center area, the CCC retains permit authority of the project site as the land is held by public trust. The Project replaces an existing commercial parking lot with three hotels (650 rooms) and a separate 3,180 square foot restaurant building. ${ }^{87}$ This case is of note because the CCC diverged from its standard cost formula and exercised considerable flexibility in its determination of the per-room in-lieu fee.

\section{Defining Local Low, Moderate, and High Cost Rates}

Like the Solana Beach case, the CCC applied the following geographic zone for the local hotels to be surveyed: San Diego County ${ }^{88}$ as the political boundary and "[h]otels in the coastal zone...within five miles of the coast" ${ }^{\prime 89}$ for distance from the coastline. To build the sample of hotels to be surveyed in the above zone, the CCC drew from single and double diamond hotels listed on the AAA Auto Club Website. The list yielded 25 hotels, eight of which were in the "coastal zone.",90

In calculating the area's cost categories, the CCC included two modifications to its standard cost formula:

86. South Coast Area Office, 5-13-0717, 1429 Hermosa, LLC, 2.

87. Ibid.

88. San Diego Area Office, 6-13-0407 (McMillin-NTC, LLC), 31.

89. Ibid.

90. Ibid. 
- $\quad$ Statewide ADR: The CCC used the 2007 Statewide ADR (\$132.90) to calculate the Local ADR Quotient, but then applied that Local ADR Quotient to the 2013 Statewide ADR (\$128.93) to find the Cost Range. ${ }^{91}$

- $\quad$ Local High Cost Point: The CCC rounded up the Cost Range for purposes of finding Local High Cost Point. The CCC explained that the purpose of this rounding was to provide a "conservative" result. ${ }^{92}$

The CCC's process in this case is detailed below in Figures 5 and 6:

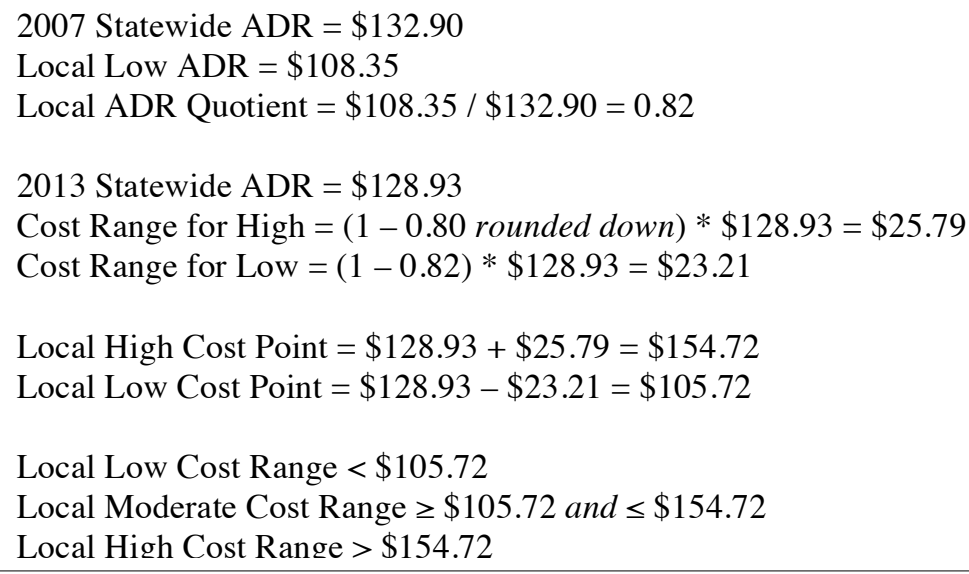

Figure 5. Lee Court: Equations for Low, Moderate, and High Cost Ranges

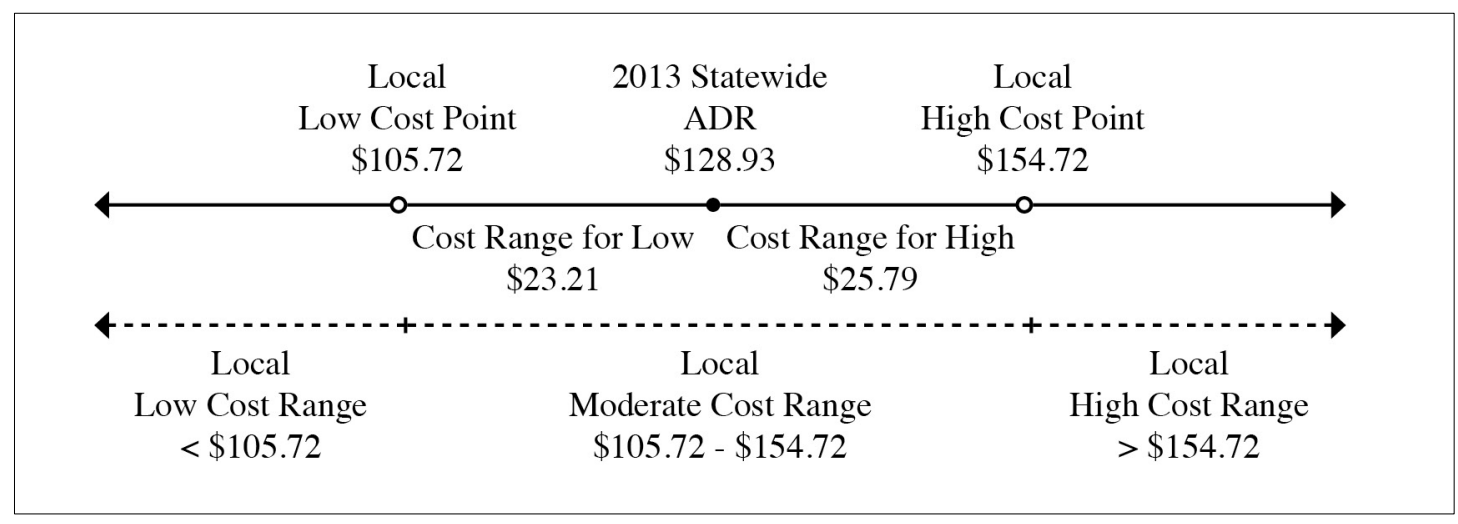

Figure 6. Lee Court: Diagram of Local Low, Moderate, and High Cost Ranges

91. Ibid., 32-33.

92. Ibid., 32 . 


\section{Determining the Per Room In-Lieu Fee}

As discussed earlier, the CCC typically applied a $\$ 30,000$ per room in-lieu fee for 25 percent of the total number of high-cost hotel rooms. However, in the case of 2200 Lee Court, the CCC applied the fee to only $12.5 \%$ of high-cost hotel rooms (compared to 25 percent of high cost rooms for Ventura and Solana Beach) for the Hotel 1 (the first of

three hotels constructed). ${ }^{93}$ At the time of the CCC's determination, Hotel 1 was slated to be 252-room all-suite hotel designed for operators such as the Embassy Suites or Spring Hill Suites. Hotel 1's projected rates were $\$ 155$ to $\$ 190$ per night, falling in the high-cost range. The $\mathrm{CCC}$ made its determination after the developer proposed the following arrangement for Hotel 1:

- $\quad$ All rooms would entail free Internet service, breakfast, and cocktail reception for guests, and

- $\quad 35$ percent of the rooms would be outfitted to accommodate up to six people per room at the standard rate..$^{94}$

The CCC found that the free amenities alone were not sufficient for reclassifying the hotel rooms as moderately priced, since many hotels in the San Diego area provide such amenities as part of their daily rates. ${ }^{95}$ However, the package of free amenities plus the agreement to configure 35 percent of the rooms for up to six people would increase overall affordability. ${ }^{96}$
93. Ibid., 33 .
94. Ibid.
95. Ibid., 34 .
96. Ibid. 
The adjusted in-lieu fee requirement nearly cuts the developer's LCOVA in-lieu fee payment by half. Applying the CCC's typical $\$ 30,000 / 25 \%$ fee for 252 high-cost hotel rooms, the developer would pay $\$ 1,890,000((0.25 * 252) * \$ 30,000=\$ 1,890,000)$. Applying the adjusted $\$ 30,000 / 12.5 \%$ fee, the CCC calculated the developer's payment at $\$ 960,000$. Because, $12.5 \%$ of 252 rooms totals 31.5 rooms, the CCC rounded the up to 32 to account for a whole number of rooms $(32 * \$ 30,000=\$ 960,000) \cdot{ }^{97}$ Rounding up to 32 rooms from 31.5 rooms adds $\$ 15,000$ to the total payment $(31.5 * \$ 30,000=\$ 945,000)$.

\section{Establishing an In-Lieu Fee Account}

In the staff report for this case, the $\mathrm{CCC}$ did not directly call for the creation of a mitigation fee account.

97. Ibid., 33 . 


\section{Chapter 5. Legal Review of In-Lieu Fees}

The LCOVA in-lieu fee constitutes a monetary exaction, for which California Courts apply differing standards of review depending on whether the fee is an ad hoc fee or a legislatively imposed fee. This chapter discusses the local authority to require exactions as permit conditions and the Federal and California law limiting that authority.

\section{Land Use Regulation Authority}

The United States Supreme Court has held that the state and local authority to regulate land use arises from the police power-capacity to regulate for health, safety, and welfare. ${ }^{98}$ The Tenth Amendment of the United States Constitution reserves for the states all powers not constitutionally delegated to the federal government, such authority reserved for states includes the police power. ${ }^{99}$ The California Constitution further extends the police power, including land use regulation, to its counties and cities. ${ }^{100}$

\section{Monetary Exactions}

Exactions are a form of land use regulation where the government requires a developer provide either property (property exaction, e.g., deeding an easement) or payment (monetary exaction, e.g., paying in-lieu fees) as a condition for approval of a permit for the proposed development. The purpose of the exaction is to offset identified potential public harms or costs associated with the proposed development. Here, the CCC

98. See Village of Euclid v. Ambler Realty Co., 272 U.S. 365, 388 (1926).

99. U.S. Const. amend. X. "The powers not delegated to the United States by the Constitution, nor prohibited by it to the States, are reserved to the States respectively, or to the people" (ibid.).

100. See Village of Euclid, 272 U.S. at 390-91. 
requires the developer to provide LCOVA facilities (property exaction) or pay an in-lieu fee to fund construction of LCOVA elsewhere (monetary exaction). The CCC's LCOVA in-lieu fee is at issue here.

Ad Hoc Fees vs. Legislatively Imposed Fees

As mentioned above, the CCC generally requires the in-lieu fee in two casesone concerning an ad hoc fee and one concerning a legislatively imposed fee.

\section{Ad Hoc Fee}

First, when a developer applies to the CCC for approval of a development permit, the CCC will impose these conditions ad hoc if it finds that a proposed development would occupy land for which LCOVA would be the preferred use. ${ }^{101}$ In this case, the $\mathrm{CCC}$ is requiring an ad hoc fee-a mitigation fee determined at agency discretion on a case-by-case basis.

\section{Legislatively Imposed Fee}

Second, when a city applies to the CCC for approval of a LCP or policy under the Commission's jurisdiction, the CCC will condition approval on the city adopting the LCOVA in-lieu fee. In this case the city is required to implement a legislatively imposed fee-a mitigation fee codified by statute, typically applied formulaically, leaving no room for agency discretion.

101. See Cal. Pub. Res. Code $\S 30222$. "The use of private lands suitable for visitor-serving commercial recreational facilities designed to enhance public opportunities for coastal recreation shall have priority over private residential, general industrial, or general commercial development, but not over agriculture or coastal-dependent industry" (ibid.). 


\section{Legal Standards}

The Unites States Supreme Court announced the constitutional rules governing property exactions in Nollan v. California Coastal Commission (the essential nexus requirement ${ }^{102}$ and Dolan $v$. City of Tigard (the rough proportionality requirement). ${ }^{103}$ In Koontz v. St. Johns River Water Management District, the Court clarified that the same rules also apply to monetary exactions, ${ }^{104}$ but left unclear whether the rules apply equally to ad hoc and legislatively imposed fees. ${ }^{105}$ However, the California Supreme Court, considering Nollan, Dolan, and the state's Mitigation Fee Act, ${ }^{106}$ has articulated differing legal standards for ad hoc fees versus legislatively imposed fees in cases of monetary exactions. ${ }^{107}$ California Courts apply the Nollan and Dolan's essential nexus and rough proportionality requirements to ad hoc fees and the Mitigation Fee Act's reasonable relationship requirement to legislatively imposed fees. ${ }^{108}$

102. Nollan v. Cal. Coastal Comm'n, 483 U.S. 825, 837 (1987).

103. Dolan v. City of Tigard, 512 U.S. 374, 391 (1994).

104. Koontz v. St. Johns River Water Mgmt. Dist., 570 U.S.__, 133 S. Ct. 2586, 2603 (2013).

105. Ibid. at 2608 (Kagan, J., dissenting).

106. The Mitigation Fee Act is codified in Cal. Gov’t Code $\S \S 6600$, et seq.

107. See San Remo Hotel v. City and County of San Francisco, 27 Cal. 4th 643, 670-671 (2002).

108. Ibid. 


\section{Federal Law}

As discussed below, the federal constitutional requirements concerning exactions - essential nexus and rough proportionality - are grounded in principals of the unconstitutional conditions doctrine and the Fifth Amendment Takings Clause. ${ }^{109}$

Unconstitutional Conditions Doctrine and The Fifth Amendment Takings Clause

The United States Supreme Court reviews exactions under legal principals of the unconstitutional conditions doctrine and the Fifth Amendment Takings Clause. Under the unconstitutional conditions doctrine, the government may not condition a benefit upon waving a constitutional right. ${ }^{110}$ Under the Fifth Amendment Takings Clause, the government may not take private property, unless for public use and with just compensation (expressed in terms of market value of the loss). ${ }^{111}$ In exaction cases, the Court considers whether the exaction (property or monetary) required for permit approval is an unconstitutional condition in that it unduly burdens the applicant's rights to just compensation under the Fifth Amendment Takings Clause. ${ }^{112}$

109. Beyond the unconstitutional conditions doctrine and the Fifth Amendment Takings Clause, the Fourteenth Amendment Equal Protection Clause (No state shall "deny to any person within its jurisdiction the equal protection of the laws" (U.S. Const. Amend. XIV, § 1.)), may be relevant to legal review of the LCOVA in-lieu fee. A developer could potentially argue that the CCC has biasedly handpicked the cases to which it applied the LCOVA in-lieu fee. In response, the CCC may argue that such is the nature of the imposition of ad hoc fees.

110. Koontz, 133 S. Ct. at 2593.

111. Ibid.

112. Ibid. 


\section{Essential Nexus and Rough Proportionality}

For a property or monetary exaction to be a valid land use regulation and not a taking, the United States Supreme Court requires it meets the essential nexus and rough proportionality tests of Nollan and Dolan, respectively. ${ }^{113}$ The essential nexus test is satisfied if the permit condition (the exaction) serves the same purpose and the objective of the condition (offsetting the potential public harms or costs of the proposed development). ${ }^{114}$ The rough proportionality test is satisfied if the exaction is roughly proportional to potential public harms or costs of the proposed development. ${ }^{115}$

Further, the Court in Koontz held that the Nollan and Dolan decisions apply to exactions (property or monetary) whether or not the permit was eventually approved or denied by the government. ${ }^{116}$ The government must offer the applicant at least one constitutional alternative for approval. However, as noted in Justice Kagan's dissent, Justice Alito's majority opinion in Koontz is unclear as to whether the Nollan and Dolan decisions apply to ad hoc fees (the type of fee at issue in Koontz) as well as legislatively imposed fees. ${ }^{117}$

113. Ibid. at 2603.

114. Nollan, 483 U.S. at 837.

115. Dolan, 512 U.S. at 391.

116. Koontz, 133 S. Ct. at 2603.

117. Ibid. at 2608 (Kagan, J., dissenting). "Perhaps the Court means in the future to curb the intrusion into local affairs that its holding will accomplish; the Court claims, after all, that its opinion is intended to have only limited impact on localities' land-use authority. The majority might, for example, approve the rule, adopted in several States, that Nollan and Dolan apply only to permitting fees that are imposed ad hoc, and not to fees that are generally applicable. See, e.g., Ehrlich v. Culver City, 12 Cal. 4th 854,911 P. 2 d 429 (1996). Dolan itself suggested that limitation by underscoring that there 'the city made an adjudicative decision to condition petitioner's application for a building permit on an individual parcel,' instead of imposing an 'essentially legislative determination[] classifying entire areas of the city.' $512 \mathrm{U}$. S., at 385. Maybe today's majority accepts that distinction; or then again, maybe not. At the least, the majority's refusal 'to say more' about the scope of its new rule now casts a cloud on every decision by 


\section{California Law}

In addition to the Nollan and Dolan decisions, California Courts cite the state's Mitigation Fee Act as a governing statute in monetary exaction cases.

\section{Reasonable Relationship}

The Mitigation Fee Act requires that the local agency imposing the fee, whether ad hoc or legislative, to show that there exists a reasonable relationship between the intended use of the fee and the impact of the proposed development and a reasonable relationship between the amount of the fee and the impact of the proposed development. ${ }^{118}$ As shown below, California Courts consider the reasonable relationship test less stringent than the essential nexus and rough proportionality tests.

Standards for Ad Hoc Fees vs. Legislatively Imposed Fees

The California Supreme Court first required that monetary exactions satisfy the essential nexus and rough proportionality requirements in Ehrlich v. City of Culver City. ${ }^{119}$ In that case and those subsequent, the Court articulated delineation in standard of review for ad hoc fees versus legislatively imposed fees. ${ }^{120}$ The Court explained that legislatively imposed fees must only meet the reasonable relationship test under the

every local government to require a person seeking a permit to pay or spend money" (some citations omitted) (ibid.).

118. Cal. Gov’t Code, $\S 6601$; See San Remo Hotel, 27 Cal. 4th at 671.

119. Ehrlich v. City of Culver City, 12 Cal. 4th 854, 881 (1996).

120. Explained above in this chapter, an ad hoc fee is determined at agency discretion on a case-by-case basis, while a legislatively imposed fee is codified by statute leaving, typically applied formulaically, leaving no room for agency discretion. 
Mitigation Fee Act, while ad hoc fees must meet the heightened scrutiny of the essential and rough proportionality tests.

In San Remo Hotel v. City and County of San Francisco, the Court explained its

distinction in standards of review was based on a comparative degree of political checks:

While legislatively mandated fees do present some danger of improper leveraging, such generally applicable legislation is subject to the ordinary restraints of the democratic political process. A city council that charged extortionate fees for all property development, unjustifiable by mitigation needs, would likely face widespread and well-financed opposition at the next election. Ad hoc individual monetary exactions deserve special judicial scrutiny mainly because, affecting fewer citizens and evading systematic assessment, they are more likely to escape such political controls. ${ }^{121}$

121. San Remo Hotel, $27 \mathrm{Cal} 4$ th at 671. 


\section{Chapter 6. Legality of the $\$ 30,000 / 25 \%$ Fee}

As explained in Chapters 2 through 4, the CCC required the LCOVA in-lieu fee upon case-by-case permit review (as an ad hoc fee) and upon review of jurisdictions' LCPs or related policy (as a legislatively imposed fee to be adopted by the jurisdiction). Chapter 5 sets forth the standards for legal review for both instances. As shown in this chapter, the $\$ 30,000 / 25 \%$ fee likely fails the applicable legal tests when required as an ad hoc fee or a legislatively imposed fee.

\section{As an Ad Hoc Fee}

The CCC applies the LCOVA in-lieu fee as an ad hoc fee when it imposes the fee on a case-by-case basis as a condition to approval of a development permit. Under California Law, ad hoc fees must meet the essential nexus and rough proportionality requirements of Nollan and Dolan. ${ }^{122}$ As generally applied in case-by-case permit review by the CCC, the LCOVA in-lieu fee most likely passes the essential nexus test, but likely fails the rough proportionality test.

\section{Essential Nexus}

In Nollan, the United States Supreme Court held that an essential nexus must exist between permit condition and the objective of the permit condition - a legitimate state interest. ${ }^{123}$ The Court explained,

122. Ibid. at 670 .

123. Nollan, 483 U.S. at 837. 
In short, unless the permit condition serves the same governmental purpose as the development ban, the building restriction is not a valid regulation of land use, but "an out-and-out plan of extortion.". 124

To satisfy Nollan's nexus requirement, the CCC's objective to mitigate exclusion of LCOVA facilities along the coast must be a legitimate state interest, and the LCOVA in-lieu fees must serve this objective. The LCOVA in-lieu fees most likely pass the essential nexus test.

Legitimate State Interest

Under Nollan, the objective of the permit condition must be a "legitimate state interest." ${ }^{125}$ The United States Supreme Court has upheld a broad range of land use objectives as constituting a legitimate state interest, including scenic zoning, landmark preservation, and residential zoning. ${ }^{126}$ Because the objective is derived from State legislation establishing land use priorities along the coast, the CCC's objective in this matter is most likely a legitimate state interest.

Across staff reports, the $\mathrm{CCC}$ points to two sections of the Coastal Act validating LCOVA mitigation policy $-30213^{127}$ and $30222 .{ }^{128}$ First, the CCC cites Section 30213 of the Public Resources Code, which charges the Commission to protect, encourage, and, where feasible, provide for lower cost visitor and recreational facilities along the State's

124. Ibid.

125. Ibid.

126. Ibid. at 834-835.

127. Cal. Pub. Res. Code $\S 30213$.

128. Ibid. § 30222 . 
coast. ${ }^{129}$ Second, the CCC cites Section 30222 of the Public Resources Code, which prioritizes development of visitor-serving uses along the coast over private residential, general industrial, or general commercial uses. ${ }^{130}$

Given its support in state statute, and that the Supreme Court has found scenic zoning and landmark preservation to be legitimate state interests, the CCC's objective to encourage and provide for LCOVA facilities is most likely a legitimate state interest.

The Nexus

Under Nollan's essential nexus test, the permit condition and the objective of the permit condition must serve the same legitimate government interest. ${ }^{131}$ For an essential nexus to exist for the LCOVA in-lieu fee, the fee must serve the objective of the fee-to mitigate preclusion of LCOVA facilities along the coast. Given the prescribed use of the fee, the LCOVA in-lieu fees most likely meets essential nexus requirement.

Here, a proposed development's impact, as identified by the CCC, is the preclusion of LCOVA facilities on site. Explained by CCC staff, The expectation of the Commission, based upon several precedents, is that developers of sites suitable for overnight accommodations will provide facilities

129. San Diego Area Office, 6-13-0407 (McMillin-NTC, LLC), 27.

130. California Coastal Commission, South Central Coast Area Office, Agenda Item 15b, Thursday, July 10, 2014, City of San Buenaventura Local Coastal Program Amendment No. SBV-MAJ-212, Th15b-7-2014, (Ventura, CA, 2014), 5-6. This CCC staff report concerned an amendment City of Ventura LCP to allow mixed-use residential parcels to be built on parcels formally zoned to allow overnight visitor accommodations. The CCC staff considered this amendment a preclusion of LCOVA facilities and required that the City charge the developer a $\$ 1.8$ million fee to provide for LCOVA accommodations. In a letter to the CCC dated July 3, 2014, the Pacific Legal Foundation questioned whether the amendment lawfully triggered an in-lieu fee given the ruling in Koontz that such fees must meet the essential nexus and rough proportionality requirements. In the staff report, the CCC responded to the essential nexus issue explaining that Section 30222 establishes a state interest in the CCC interest in preventing the preclusion of LCOVA facilities. The staff report, however, did not seem to respond to the rough proportionality issue.

131. Nollan, 483 U.S. at 837. 
which serve people with a range of incomes. If development cannot provide for a range of affordability on-site, the Commission requires off-site mitigation. ${ }^{132}$

When imposed by CCC, LCOVA in-lieu fees are expressly collected for the "the acquisition, construction or renovation of lower cost accommodations along the California Coast." ${ }^{\prime 33}$ Of the $\$ 19.2$ million in LCOVA in-lieu fees available (\$16.7 million in fees collected since 1979 earning $\$ 2.5$ million in interest), the CCC spent $\$ 8.6$ million toward mitigation preclusion of LCOVA facilities. ${ }^{134}$ These facilities include, among other projects construction of a 260-bed hostile in Santa Monica, a 100-bed hostile in Santa Barbara, and rehabilitation of the Crystal Cove Cottages. ${ }^{135}$

In general, the intended and actual use of the LCOVA in-lieu fees serve the same legitimate government interest as the objective of the fee-to mitigate preclusion of LCOVA facilities along the coast - thus meeting the essential nexus requirement. ${ }^{136}$ Rough Proportionality

In Dolan, the United States Supreme Court held that a permit condition must be roughly proportional to the potential harm of the proposed development. ${ }^{137}$ The Court explained,

132. San Diego Area Office, 6-13-0407 (McMillin-NTC, LLC), 27-28.

133. California Coastal Commission, Status Report on In-Lieu Fees, 1.

134. Ibid.

135. Ibid., 6-12.

136. The issue here is not whether or not the fee is effective in its service of the legitimate state interest. In Lingle v. Chevron U. S. A. Inc., 544 U.S. 528 (2005), the United States Supreme Court held that the "substantially advance[s] a legitimate state interest" test is not appropriate for cases under Fifth Amendment Takings Clause. In her majority opinion, Justice O'Connor explained that the "substantially advances" test is a question of whether the regulation was effective, and does not explain whether the regulation was a taking - a question of the "magnitude or character of the burden a particular regulation imposes upon private property rights" (ibid. at 542). 
No precise mathematical calculation is required, but the city must make some sort of individualized determination that the required dedication is related both in nature and extent to the impact of the proposed development. ${ }^{138}$

California Courts have emphasized the decision's use of the terms “individualized determination" and "nature and extent to the impact." ${ }^{139}$ For the LCOVA in-lieu fee to satisfy the Dolan's rough proportionality requirement, the CCC must make an individualized determination that the fee is roughly proportional to the nature and extent of the proposed development's impact. The LCOVA in-lieu fee likely fails this test.

Nature and Extent of Impact

To determine whether the LCOVA in-lieu fee is roughly proportional in nature and extent to offending development impacts, the nature and extent of the impact must first be identified. As mentioned above, the CCC's position is that the not that a development necessarily creates a need for LCOVA facilities, but that it precludes the provision of LCOVA facilities on that site. However, the significance of the impact of the preclusion likely varies based on location.

LCOVA Preclusion. The following three examples illustrate the CCC's classification of the impact.

137. Dolan, 512 U.S. at 391.

138. bid. 229 (2008).

139. Ocean Harbor House Homeowners Ass'n v. Cal. Coastal Comm'n, 163 Cal.App.4th 215, 
- A non-hotel development, such as a residential subdivision, on land suitable for LCOVA facilities would likely compose a total preclusion of LCOVA facilities. ${ }^{140}$

- A hotel development where all room rates are in the higher price range may also compose a total preclusion of LCOVA facilities.

- A hotel development includes a mix of LCOVA and higher prices facilities may be considered less than a total preclusion of LCOVA facilities. ${ }^{141}$

This position considers nature and extent of the impact of LCOVA preclusion in absolute terms, which is compatible with the context of state-wide deficiency of LCOVA supply presented by CCC staff reports; if the LCOVA facility inventory for the California Coastal Zone at-large is lacking, then all lost opportunities to construct new facilities could be counted as virtually equal impacts. However, a California precedent likely requires that the impact be defined in a narrower scope.

Impacts in the Local Context. In California Building Industry Association v. City of San Jose, ${ }^{142}$ the California Court of Appeal for the Sixth District related the holding in Shapell Industries, Inc. v. Governing Board, ${ }^{143}$

140. City of San Buenaventura No. City of San Buenaventura, 5. This CCC staff report concerned an amendment City of Ventura LCP to allow mixed-use residential parcels to be built on parcels formally zoned to allow overnight visitor accommodations. The CCC staff considered this amendment a preclusion of LCOVA facilities and required that the City charge the developer a $\$ 1.8$ million fee to provide for LCOVA accommodations.

141. San Diego Area Office, 6-13-0407 (McMillin-NTC, LLC), 33-34. As discussed in Chapter 4 , in the 2200 Lee Court project, the CCC imposed a $\$ 30,000 / 12.5 \%$ fee given the development's proposed free amenities and accommodation of rooms for more guests.

142. Cal. Building Industry Ass'n v. City of San Jose, 216 Cal.App.4th 1373 (2013).

143. Shapell Industries, Inc.v. Governing Board, 1 Cal.App.4th 218 (1991). 
In Shapell the very purpose of the school facilities fee was to accommodate a growing student population and reduce overcrowding of schools caused by new development. The fee was improper to the extent that the assessment was based on an estimated increase in student population overall rather than on the increase generated by the new housing itself. We declined to second-guess the district's methods of deriving its supporting data, but we insisted that a "reasoned analysis" be conducted "to establish the requisite connection between the amount of the fee imposed and the burden created" by the development. (Citation omitted). The district was required only to "make a reasonable choice after considering the relevant factors." (Citation omitted). Thus, it had to "demonstrate that development contributes to the need for the facilities, and that its choices as to what will adequately accommodate the influx of students are reasonably based." (Citation omitted)..$^{144}$

In Shapell, the Court found that a fee charged to a specific development must be based on that development's impact, not a wider trend indicating a need for additional public facilities. As discussed above, the CCC defines the impact of developments charged the LCOVA in-lieu fee as preclusion of LCOVA facilities along the California coast - an impact tied to the statewide trend. However, the nature and extent of the impact of LCOVA preclusion likely varies depending on the location of the development.

Accordingly, a more accurate identification of the extent and nature of the impact would include the degree of LCOVA preclusion in the context of the local conditions.

Individualized Determination of Rough Proportionality

Under Dolan, The United States Supreme Court requires that the agency make an individual determination, with some effort to quantify its findings, that the fee is roughly

144. Cal. Building Industry Ass'n, 216 Cal.App.4th at 1386. The Court explained that the test applied in Shappel "was drawn from California Hotel \& Motel Assn v. Industrial Welfare Com. (1979) 25 Cal.3d 200, 212 [157 Cal.Rptr. 840, 599 P.2d 31]: 'A court will uphold the agency action unless the action is arbitrary, capricious, or lacking in evidentiary support. A court must ensure that an agency has adequately considered all relevant factors, and has demonstrated a rational connection between those factors, the choice made, and the purposes of the enabling statute"' (ibid. at 1385). 
proportional to the impact of the development. ${ }^{145}$ As mentioned above, the $\mathrm{CCC}$ applies a formula to define the higher cost rage - the room rates at which the LCOVA in-lieu fee is triggered for a development project. Typically, the CCC imposes the $\$ 30,000 / 25 \%$ fee for a proposed development's rooms in the higher cost range. This method cannot individually determine a LCOVA in-lieu fee roughly proportional to the nature and extent of impacts of proposed development for three reasons:

1. It will virtually always generate an in-lieu fee for nearly any proposed hotel development;

2. It fails to adequately account for local conditions, such as existing LCOVA facilities and other accommodations; and

3. The in-lieu fee it imposes is not supported by substantial evidence. ${ }^{146}$

Regular Generation of an In-Lieu Fee. First, the CCC's formula cannot individually determine a fee roughly proportional to the development's impact because the formula virtually always generates a fee. As explained above, the formula calculates an in-lieu fee by identifying the Local High Cost Range, based on a difference between the Local Low ADR (the average ADR for hotels below the statewide ADR) and statewide ADR. So long as the local hotel inventory includes at least one hotel with an ADR below the statewide average, the formula will produce an in-lieu fee. A local hotel inventory that includes no hotels below the statewide ADR will confound the formula and fail to generate an in-lieu fee. Further, as below, the Local Low ADR does not adequately measure the affordability of the local hotel inventory.

145. Dolan, 512 U.S. at 391.

146. Cal. Building Industry Ass'n, 216 Cal.App.4th at 1386. 
Local Conditions. Second, the CCC's formula does not adequately account for local conditions concerning overnight accommodations affordability, and therefore cannot produce an in-lieu fee roughly proportional to the development's impacts, for three reasons:

1. The Local ADR does not represent the overall affordability of the inventory,

2. Facilities defined by the CCC as inherently LCOVA are not included, and

3. Local lower-cost hotels included in the statewide ADR are not included in the local hotel inventory for purposes of the formula.

Local Low ADR. The Local Low ADR does not represent the overall affordability of the local hotel inventory. Consider the following illustration of hypothetical City A and City B with an assumed statewide ADR of \$130:

Table 3. Hypothetical Hotel Inventories for City A and City B

\begin{tabular}{|c|c|c|c|c|c|c|c|c|c|c|}
\hline Hotel & 1 & 2 & 3 & 4 & 5 & 6 & 7 & 8 & 9 & 10 \\
\hline City A & $\$ 125$ & $\$ 125$ & $\$ 125$ & $\$ 125$ & $\$ 125$ & $\$ 125$ & $\$ 125$ & $\$ 125$ & $\$ 130$ & $\$ 150$ \\
\hline City B & $\$ 90$ & $\$ 110$ & $\$ 130$ & $\$ 130$ & $\$ 150$ & $\$ 150$ & $\$ 175$ & $\$ 175$ & $\$ 200$ & $\$ 200$ \\
\hline
\end{tabular}

Table 4. Hypothetical ADR Figures for City A and City B

\begin{tabular}{|l|r|r|r|r|}
\hline & Local ADR & Local Low ADR & Statewide ADR & Local High Cost Range \\
\hline City A & $\$ 128$ & $\$ 125$ & & $\$ 130$ \\
\cline { 1 - 1 } \cline { 5 - 5 } City B & $\$ 151$ & $\$ 100$ & & $\$ 135$ \\
\hline
\end{tabular}

As shown in Tables 3 and 4, eight of ten hotels in City A are below the statewide ADR, while only two of ten hotels in City B are below the statewide ADR. Further, City A's overall ADR (\$128) is \$2 below the statewide ADR (\$130), while City B's overall ADR (\$151) is \$31 above. Indecently, the Local Low ADR for City A (\$125) is higher 
than for City B (\$100). However, these that figures demonstrating relative affordability are not factored into the Local Low ADR. Considering the statewide ADR, the Local High Cost Range for City A is $\$ 135$ and for City B is $\$ 160$. This means that a hotel built in City A will pay the $\$ 30,000 / 25 \%$ fee for rooms over $\$ 135$, which is a harsher penalty than would be exacted on City B.

Because the formula may produce a harsher penalty for a City with greater hotel affordability than another, the LCOVA in-lieu fee is likely not applied in a manner "roughly proportional."

"Inherently Lower Cost" Inventory. When compiling the local hotel inventory, the CCC draws from AAA-rated properties, which excludes facilities the CCC considers as “inherently lower cost,” such as hostiles, campsites, and potentially RV parks. ${ }^{147}$ Therefore, these facilities may not contribute to a Local Low ADR. Because the formula fails to account for the local stock of inherently LCOVA facilities, the formula is again producing an in-lieu fee absent consideration the full picture of local affordability.

AAA-rated Properties. Further, the CCC compiles local hotel inventories from a different subset of hotels in California than is used for the statewide average. As discussed in Chapter 3, the CCC only considers AAA-rated properties when surveying hotels within the defined relevant local area to identify the Local Low ADR to ensure only quality hotels are counted. However, the Smith Travel Research ("STR") trend reports, from which the CCC obtains the statewide ADR figure, likely include rates of many hotels that are not AAA-rated. Hotels that are not AAA-rated may be lower cost

147. South Coast Area Office, LOB-MAJ-1-10 (1-10) City of Long Beach, 33. 
than those that are. Accordingly, a local area's lower cost non-AAA-rated hotels counted in the Statewide ADR may not counted towards the local area's affordability.

The CCC's different application of AAA ratings in inventories presents two problems with assessments of hotel affordability in the state and local areas. The first problem is the possible deflation of the statewide ADR and inflation of the local area ADR, which in turn impacts the CCC's imposition of the in-lieu fee. The second problem is a negation of a quality control measure enacted by the CCC in local hotel inventories, since the CCC applies this measure to the local inventory, but not the statewide. These two problems further hinder the formula's capacity to produce a fee that is roughly proportional.

Source of the $\$ 30,000$ Base Fee. Third, the $\$ 30,000 / 25 \%$ fee was likely derived from a source with conflicting interests and therefore likely not based on substantial evidence. As discussed in Chapter 3, the CCC, in 2006, determined the $\$ 30,000$ base fee for the LCOVA in-lieu fee based on information provided by Hostelling International (“HI”) - a nonprofit global membership organization of youth hostels. ${ }^{148}$ However, the $\mathrm{CCC}$ has in some cases named $\mathrm{HI}$ as an option a jurisdiction may select to manage the LCOVA in-lieu fee account. ${ }^{149}$ However, Hostelling International and its affiliate organization, American Youth Hostels (“AYH”) (also known as Hostelling International USA), ${ }^{150}$ have also been primary beneficiaries of this in-lieu fee.

148. Hostelling International, “About Hostelling International,” last modified 2014, https://www.hihostels.com/about-hi/about-hostelling-international

149. South Coast Area Office, 5-13-0717, 1429 Hermosa, LLC, 18.

150. Hostelling International USA, “About HI-USA,” last modified 2013, http://www.hiusa.org/about-us 
In 2010, the CCC produced an inventory of "CCC Special Deposit Account Funds held by the State Controller." ${ }^{151}$ The inventory covered 19 cases where accounts were created. $\mathrm{HI}$ or AYH was the recipient of the funds in seven cases and the intended recipient in two. ${ }^{152}$ Given HI's status as a CCC-designated recipient of the LCOVA inlieu fees, it is most likely a biased source on which to rely for the amount of the fee.

\section{As a Legislatively Imposed Fee}

When the CCC requires that a city adopt the $\$ 30,000 / 25 \%$ fee as a condition of approval of the city's LCP or related policy, city will generally adopt the fee as a legislatively imposed ordinance. Along with the differences between ad hoc fees and legislatively imposed fees, there is another key distinction: As a legislatively imposed fee, the $\$ 30,000 / 25 \%$ is part of the city's municipal code, meaning that the city, not the $\mathrm{CCC}$, is entity ultimately responsible for the enforcement and operation of the fee. Accordingly, in this case, the city is party burdened with defense the $\$ 30,000 / 25 \%$ fee's legality.

California Courts apply a different standard for legislatively imposed fees than ad hoc fees. The standard for legislatively imposed fees - the reasonable relationship testis derived from State's Mitigation Fee Act. The California Supreme Court articulated the elements of this test as follows:

As a matter of both statutory and constitutional law, such fees must bear a reasonable relationship, in both [1] intended use and [2] amount, to the deleterious public impact of the development. ${ }^{153}$

151. California Coastal Commission, Status Report on In-Lieu Fees, 6-12.

152. Ibid.

153. San Remo Hotel, 12 Cal. 4th at 671. 
The Court has explained that the reasonable relationship test, although less stringent than the essential nexus and rough proportionality tests, is still a "meaningful means-ends review:"154

While the relationship between means and ends need not be so close or so thoroughly established for legislatively imposed fees as for ad hoc fees subject to Ehrlich, the arbitrary and extortionate use of purported mitigation fees, even where legislatively mandated, will not pass constitutional muster. ${ }^{155}$

Explained above, the reasonable relationship test is composed of two elements:

1. The fee's intended use must be reasonably related to the development's impact, and

2. The fee's amount must be reasonably related to the development's impact. When the $\$ 30,000 / 25 \%$ fee is adopted by a jurisdiction as required by the CCC as a condition to approval of an LCP or related policy, it is likely that the $\$ 30,000 / 25 \%$ fee fails the reasonable relationship test. The fee may bare an reasonable relationship between its intended use and the development's impact, but the relationship between the fee's amount and the development's impact is likely insufficiently distant.

\section{Use Of Fees-Impact of Development Connection}

Under the Mitigation Fee Act, there must exist a reasonable relationship between the intended use of the fees and the impact of the proposed development. This element of the reasonable relationship test is virtually the same principle as Nollan's essential nexus test. Here again, the development's impact is LCVOA preclusion and the intended use of

154. Ibid.

155. Ibid. 
the fees is LCOVA provision. Imposed legislatively, the $\$ 30,000 / 25 \%$ fee likely bears a reasonable relationship between its intended use and the development's impact.

\section{Amount of Fees-Impact of Development Connection}

Under the Mitigation Fee Act, there must also exist a reasonable relationship between the amount of the fees and the impact of the development. This element of the reasonable relation test is similar to, but less strict than, to the rough proportionality test. Imposed legislatively, the fee amount-impact connection for the $\$ 30,000 / 25 \%$ fee is likely far too attenuated to pass muster under the reasonable relationship test.

Shown in breakdown performed in Chapter 2, there are three numbers that determine the amount of the LCOVA in-lieu fee:

- The definition higher cost rooms (determined by formula),

- $\quad$ The base fee $(\$ 30,000)$, and

- $\quad$ The rate at which the base fee is charged (25 percent of higher cost rooms).

Three of the four case studies in Chapter 4 concern the adoption of the LCOVA in-lie fee byway of LCP:

- $\quad$ City of Ventura, LCP Amendment (2008),

- $\quad$ City of Long Beach, LCP Amendment (2010), and

- $\quad$ City of Solana Beach, LCP Land Use Plan (2012).

Table 5 shows that each of the three case studies, the CCC, with minor exception, locked in the number for each of the three figures as a condition of approval: 
Table 5. Local Discretion in Adoption of the LCOVA In-Lieu Fee

\begin{tabular}{|l|l|l|}
\hline \multicolumn{1}{|c|}{$\begin{array}{c}\text { City of Ventura, LCP } \\
\text { Amendment (2008) }\end{array}$} & \multicolumn{1}{c|}{$\begin{array}{c}\text { City of Long Beach, LCP } \\
\text { Amendment (2010) }\end{array}$} & \multicolumn{1}{c|}{$\begin{array}{c}\text { City of Solana Beach, LCP } \\
\text { Land Use Plan (2012) }\end{array}$} \\
\hline \begin{tabular}{l|l|} 
Definition of Higher Cost Rooms \\
$\begin{array}{l}\text { Set at 25\% greater than } \\
\text { statewide ADR. }\end{array}$
\end{tabular} & $\begin{array}{l}\text { Set at 25\% greater than } \\
\text { statewide ADR. }\end{array}$ & $\begin{array}{l}\text { Set at 20\% greater than } \\
\text { statewide ADR, with some } \\
\text { flexibility for reevaluation over } \\
\text { time. }\end{array}$ \\
\hline Base Fee & Set at \$30,000. & $\begin{array}{l}\text { Set at \$30,000 (in 2007) and } \\
\text { adjusted for inflation. }\end{array}$ \\
\hline Set at \$30,000. & Set at 25\%. & Set at 25\%. \\
\hline Rate at Which Base Fee is Charged
\end{tabular}

As explained in Chapter 5, legislatively imposed fees are distinguished from ad hoc fees, in part, because legislatively imposed fees are imposed without discretion and are crafted through the political process for approval by an elected body. As required by the $\mathrm{CCC}$ in the cases above, the $\$ 30,000 / 25 \%$ fee leaves the local jurisdiction little to no room for discretion in the fee's application. The concern here, however, is that the fees were determined without sufficient consideration of local affordability conditions. As discussed earlier in this chapter all three figures (the definition of higher cost rooms, the base fee, and rate at which the base fee is charged) present issues of bias and lack of specificity. Accordingly, there is likely an insufficient connection between the fee's amount and the development's impact. 


\section{Chapter 7. Recommendations}

The preceding chapters present a number of policy and legal problems posed by the $\$ 30,000 / 25 \%$ fee. This chapter presents recommendations for developers, coastal jurisdictions, and the CCC when facing and imposing the fee.

\section{For Developers}

There are two situations when developers may face the prospect of the $\$ 30,000 / 25 \%$ fee:

- When applying for a CDP with the CCC, or

- When applying for a development permit with a development permit with a coastal jurisdiction that adopted the $\$ 30,000 / 25 \%$ fee.

Below are recommendations for each situation.

When Facing a CCC-required Ad Hoc Fee

Broadly, a developer facing the $\$ 30,000 / 25 \%$ fee upon application for a CDP has three options:

- $\quad$ Challenge the fee as unconstitutional,

- $\quad$ Propose an alternative mitigation policy, or

- $\quad$ Propose a reduced fee based on the development's affordability.

Challenge the Fee as Unconstitutional

As shown in Chapter 6 , the $\$ 30,000 / 25 \%$ fee required as an ad hoc fee likely presents troublesome constitutional issues under Dolan's rough proportionality 
requirement. However, challenging the $\mathrm{CCC}$ in court can financially exhausting process. The cost of litigation in terms of money and time can quickly tip the cost-benefit scale, particularly when considering that the CCC, represented by the California Attorney General, does not necessarily weigh the same factors as developers.

Propose and Alternative Mitigation Policy

The Ventura LCP Amendment case discussed in Chapter 4 suggests that that CCC may be open to entertaining alternative approaches to LCOVA mitigation other than the $\$ 30,000 / 25 \%$ fee. Developing an alternative may require expenditures toward data collection to determine the local affordability conditions, but would likely be far less costly than litigation.

Propose a Reduced Fee

The 2200 Lee Court case discussed in Chapter 4 may be instructive to developers. In this case, the CCC agreed to reduce the rate at which the base fee $(\$ 30,000)$ is applied (from 25 percent to 12.5 percent), effectively reducing the total fee by half, after the developer agreed to (1) provide lower cost visitor serving amenities and (2) outfit a number of standard-priced rooms to be comfortably occupied by a family of six. ${ }^{156}$ Two qualifications should be considered when pursing this approach. First, the 2200 Lee Court case made clear that $\mathrm{CCC}$ would require both the amenities and an effort reduce rates (such as outfitting the rooms for more people) to consider a reduced LCOVA in-lieu fee. ${ }^{157}$ Second, the degree to which prior CCC staff reports and decisions serve as

156. San Diego Area Office, 6-13-0407 (McMillin-NTC, LLC), 33.

157. Ibid., 34 . 
authorities precedents is unclear. Although CCC staff reports often site prior reports and decision in a manner that suggests the weight of precedents, they may not be necessarily binding of in future cases. ${ }^{158}$

When Facing a Coastal Jurisdiction-adopted Legislatively Imposed Fee

Given Chapter 6's findings that the $\$ 30,000 / 25 \%$ fee, when imposed legislatively, likely fails the reasonable relationship test under the Mitigation Fee Act, developers may choose to challenge the fee when required by a jurisdiction's LCP. The formulaic nature of legislatively imposed fees leaves little room for negotiation for either the developer or the jurisdiction. However, as discussed below, the developer's and jurisdiction's interests may be aligned in challenging the fee.

\section{For Coastal Jurisdictions}

Similar to developers discussed above, coastal jurisdictions may have a range of options when posed with the $\$ 30,000 / 25 \%$ fee. Unlike developers, coastal jurisdictions may have to contend with the fee as part of its municipal code.

158. See South Coast Area Office, LOB-MAJ-1-10 (1-10) City of Long Beach, 34-35. "[T]he expectation of the Commission is that developers of sites suitable for overnight accommodations will provide facilities which serve people with a range of incomes. If the development cannot provide for a range of affordability on-site, then off-site mitigation has been required in past commission actions [HNBMAJ-2-06 (Huntington Beach-Timeshares), San Diego Unified Port District Port District A-6-PSD-804/101(Lane Field), A-5-RPV-2-324 (Long Point), RDB-MAJ-2-08 (Redondo Beach), SBV-MAJ-2-08 (Ventura) \& 5-98-156-A17 (Long Beach Pike)]...Recent Commission decisions for individual development projects (6-92- 203-A4/KSL, A-6-ENC-07-51, Oceanside LCPA 1-07 \& Redondo Beach LCPA 2-08) have required the payment of an in-lieu charge of $\$ 30,000$ paid for each required replacement room as a part of the mitigation package. For high cost overnight visitor accommodations where low cost alternatives are not included onsite, a mitigation charge of $\$ 30,000$ per room is being required for twentyfive percent (25\%) of the high cost rooms constructed (Permit Amendment 5-98-156-A17)" (ibid.). 
When Facing a CCC-Required Fee

Discussed above, the $\$ 30,000 / 25 \%$ fee as a legislatively imposed fee likely violates the Mitigation Fee Act. Coastal jurisdictions should be thoroughly vet the CCC's required LCOVA in-lieu before adopting the fee into its municipal code. Further, the local jurisdiction should conduct its own survey of coastal hotel rates, both in the Coastal Zone and the Five Mile Zone, to evaluate whether any LCOVA mitigation is warranted. If an affordability issue exists, the jurisdiction should propose to the CCC a LCOVA mitigation policy that best reflects the local conditions.

\section{After Adoption of a CCC-Required Fee}

Jurisdictions who have already adopted the $\$ 30,000 / 25 \%$ fee may have recourse under the Coastal Act, should it chose to strike the fee from its code. Public Resources Code Section 3005.5 limits the CCC's authority to require cities to enact laws outside of the city's authority:

Nothing in this division [the Coastal Act] shall be construed to authorize any local government, or to authorize the commission to require any local government, to exercise any power it does not already have under the Constitution and laws of this state or that is not specifically delegated pursuant to Section 30519 [which sets forth the procedure for preparation, approval, and certification of LCPs]. ${ }^{159}$

Accordingly, the CCC cannot condition approval of a city's application for an

LCP amendment or other policy upon the city adopting an ordinance beyond its authority. However, since the CCC approved the LCP amendment, it is unclear if the CCC may or may not revisit the LCOVA issue in the LCP amendment should the fees be stricken as unenforceable.

159. Cal. Pub. Res. Code $\S 3005.5$. 


\section{For the CCC}

As mentioned in Chapter 1, the CCC recently revisited this its policy and practice regarding LCOVA mitigation. In its study and deliberation of this issue, the CCC should consider the following:

- $\quad$ Develop a LCOVA mitigation practice that better reflects the local hotel affordability conditions. If local conditions are more accurately accounted for in the fee generation formula, it may be a step to remedying the Dolan problems.

- $\quad$ Reevaluate the $\$ 30,000$ base fee amount reasoning with greater transparency and with additional sources beyond the HI letter.

- $\quad$ Explain the reasoning behind the 25 percent figure. CCC staff reports yield little to no relevant information as to how this figure was developed.

- $\quad$ Clarify the role of CCC staff reports and decisions as precedents for future actions. 


\section{References}

California Building Industry Association v. City of San José, 216 Cal.App.4th 1373 (2013).

California Coastal Commission. California Coastal Commission Strategic Plan 20132018. San Francisco, CA, 2013.

___. "Commissioner Biographies." Last modified 2015, http://www.coastal.ca.gov/bios.html

___. "Commissioners \& Alternates." Last modified 2015, http://www.coastal.ca.gov/roster.html

——. Friday, March 13, 2015 9:00 A.M.: Public Workshop: Lower Cost Visitor Serving Accommodations (Video). Accessed April 15, 2015, Retrieved from http://www.cal-span.org/cgi-bin/archive.php?owner=CCC\&date=2015-03$13 \&$ player=jwplayer\&captions $=$

_- Local Coastal Program (LCP) Update Guide. San Francisco, CA, 2013.

___. "Local Coastal Programs (LCPs)." Last modified 2015, http://www.coastal.ca.gov/lcps.html

___. "Permanent Responsibilities of the California Coastal Commission." Last modified 2015, http://www.coastal.ca.gov/perresp.html

__- "Procedural Guidance for the Review of Wetland Projects in California's Coastal Zone: Chapter 1 - Coastal Development Review Process." Last modified June 15, 1994, http://www.coastal.ca.gov/wetrev/wettitle.html

-_- Public Workshop: Lower Cost Visitor Serving Accommodations Final Agenda (December 10, 2014). W3-12-2014. San Francisco, CA, 2014.

- - Public Workshop: Lower Cost Visitor Serving Accommodations Final Agenda (March 13, 2014). F9-3-2015. San Francisco, CA, 2015.

-_- Status Report on In-Lieu Fee Mitigation for Impacts to Lower-Cost Overnight Accommodations. By Peter M. Douglas, Susan Hanscj, Charles Lester, Elizabeth A. Fuchs, Nicholas Dreher. F14c-5-2010. San Francisco, CA, 2010.

___. "What We Do: Program Overview." Last modified 2015, http://www.coastal.ca.gov/whoweare.html 
California Coastal Commission, San Diego Area Office. Addendum to Item Th16e, Coastal Commission Permit Application \#6-13-0407 (McMillin-NTC, LLC), for the Commission Meeting of February 13, 2014. Th16e-2-2014. San Diego, CA, 2014.

Revised Findings on City of Solana Beach LCP Land Use Plan for Commission Meeting of June 13-15, 2012. By Sherilyn Sarb, Deborah Lee, and Diana Lilly. Th24a-6-2012. San Diego, CA, 2012.

-_- Staff Recommendation on San Diego Unified Port District Port Master Plan Amendment No. 46 (PMP-6-PSD-14-0002-6) East Harbor Island. For Commission consideration and possible action at the Meeting of July 9-11, 2014. By Sherilyn Sarb, Deborah Lee, Amanda Sackett. W18b-7-2014. San Diego, CA, 2014.

California Coastal Commission, South Central Coast Area Office. Agenda Items 11a and 11 b, City of San Buenaventura Local Coastal Program (LCP) Amendment SBVMAJ-1-08 [Midtown Corridor Development Code-Main Street and Thompson Boulevard] and SBV-MAJ-2-08 [Downtown Specific Plan] for Public Hearing and Commission Action at the California Coastal Commission hearing of November 5, 2009 in Long Beach. Th11a-11-2009. Ventura, CA, 2009.

-_- Agenda Item 15b, Thursday, July 10, 2014, City of San Buenaventura Local Coastal Program Amendment No. SBV-MAJ-2-12. Th15b-7-2014. Ventura, CA, 2014.

California Coastal Commission, South Coast Area Office. Major Amendment Request No. LOB-MAJ-1-10 (1-10) to the City of Long Beach Certified Local Coastal Program. For Public Hearing and Commission action at the Commission's June 16, 2011 Meeting in Marina del Ray. By John Ainsworth, Gary Timm, and Charles Posner. Th18a-6-2011. Long Beach, CA, 2011.

-—. Staff Report: Regular Calendar, Application No.: 5-13-0717, Applicant: 1429 Hermosa, LLC. F10a-6-2014. Long Beach, CA, 2014.

California Government Code Sections 6600, et seq., 6601.

California Public Resources Code Sections 30000, et seq., 3005.5, 30103(a), 30213, 30222.

Dolan v. City of Tigard, 512 U.S. 374 (1994).

Ehrlich v. City of Culver City, 12 Cal. 4th 854 (1996).

Hostelling International USA. “About HI-USA.” Last modified 2013, http://www.hiusa.org/about-us 
Hostelling International. “About Hostelling International.” Last modified 2014, https://www.hihostels.com/about-hi/about-hostelling-international

Koontz v. St. Johns River Water Management District, 570 U.S. _, 133 S. Ct. 2586 (2013).

Lingle v. Chevron U. S. A. Inc., 544 U.S. 528 (2005).

Lisa Wise Consulting, Inc. Staff Interview with City of Ventura, Community Development Department Staff. July 24, 2014.

Lori Weinberg. "Harbor Island Hotel Faces Delay." San Diego Union-Tribune. July 9, 2014. Accessed July 25, 2014, http://www.utsandiego.com/news/2014/Jul/09/harbor-island-hotel-delayedcoastal-commission/

Nollan v. California Coastal Commission, 483 U.S. 825 (1987).

Ocean Harbor House Homeowners Assn. v. California Coastal Commission, 163 Cal.App.4th 215 (2008).

Sabatier, Paul A. and Daniel A. Mazmanian. Can Regulation Work?: The Implementation of the 1972 California Coastal Initiative. New York, NY: Plenum Press, 1983.

San Remo Hotel v. City and County of San Francisco, 27 Cal. 4th, 643 (2002).

Shapell Industries, Inc.v. Governing Board, 1 Cal.App.4th 218 (1991).

United States Constitution Amendments X; XIV, Section 1.

Village of Euclid v. Ambler Realty Co., 272 U.S. 365 (1926). 